
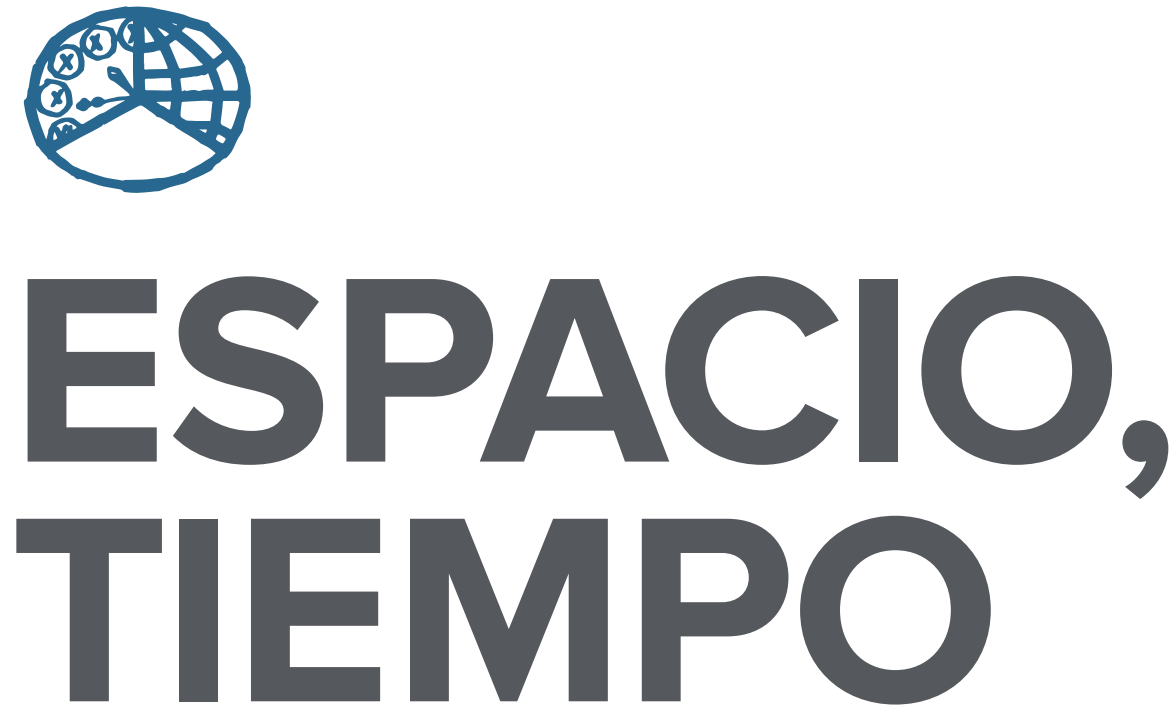

AÑO 2013

NUEVA ÉPOCA

ISSN 1130-4715

E-ISSN 2340-1478
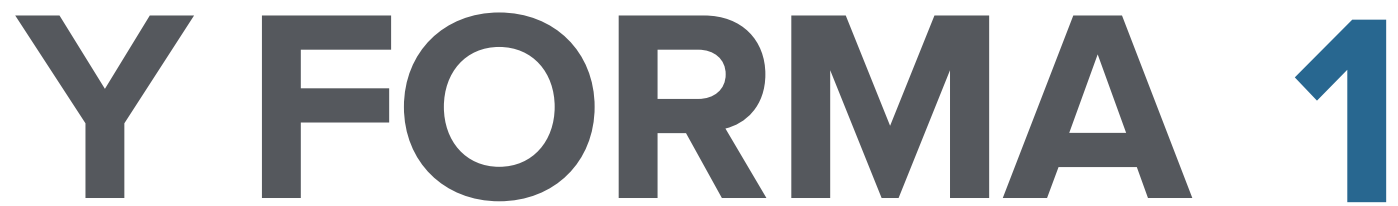

SERIE VII HISTORIA DEL ARTE

REVISTA DE LA FACULTAD DE GEOGRAFÍA E HISTORIA 

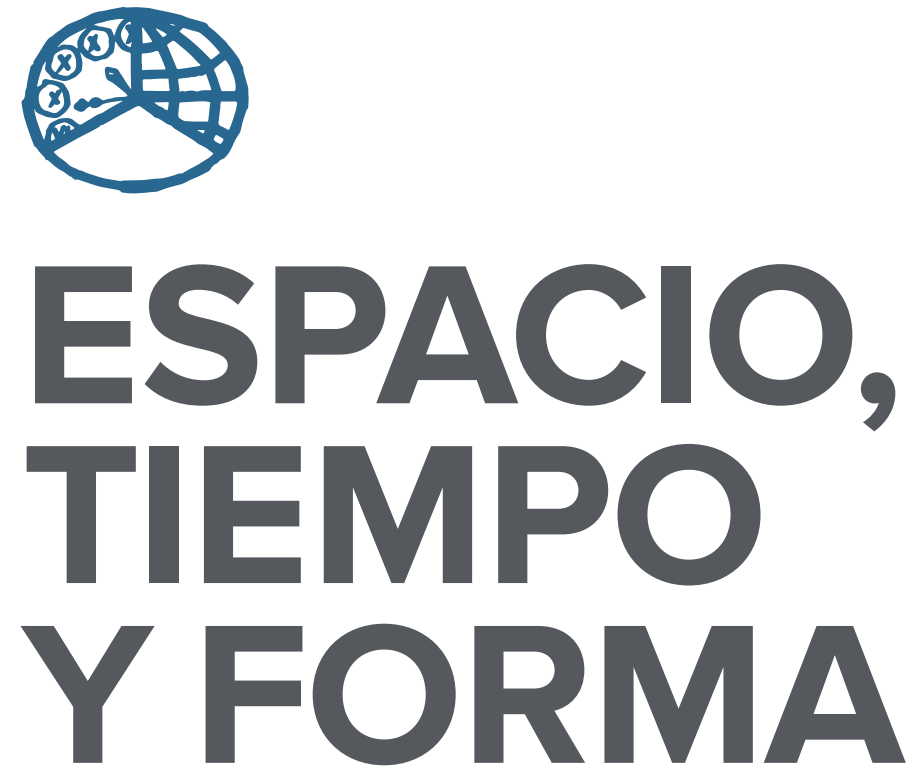

AÑO 2013

NUEVA ÉPOCA

ISSN $1130-4715$

E-ISSN 2340-1478

SERIE VII HISTORIA DEL ARTE

REVISTA DE LA FACULTAD DE GEOGRAFÍA E HISTORIA

http://dx.doi.org/10.5944/etfvii.1.2013

\section{UกED}

UNIVERSIDAD NACIONAL DE EDUCACIÓN A DISTANCIA 
La revista Espacio, Tiempo y Forma (siglas recomendadas: ETF), de la Facultad de Geografía e Historia de la UNED, que inició su publicación el año 1988, está organizada de la siguiente forma:

$$
\begin{aligned}
& \text { SERIE I - Prehistoria y Arqueología } \\
& \text { SERIE II - Historia Antigua } \\
& \text { SERIE III - Historia Medieval } \\
& \text { SERIE IV - Historia Moderna } \\
& \text { SERIE V - Historia Contemporánea } \\
& \text { SERIE VI - Geografía } \\
& \text { SERIE VII - Historia del Arte }
\end{aligned}
$$

Excepcionalmente, algunos volúmenes del año 1988 atienden a la siguiente numeración:

$$
\begin{aligned}
& \mathrm{N}^{\circ} 1 \text { - Historia Contemporánea } \\
& \mathrm{N}^{\circ} 2 \text { - Historia del Arte } \\
& \mathrm{N}^{\circ} 3 \text { - Geografía } \\
& \mathrm{N} .^{\circ} 4 \text { - Historia Moderna }
\end{aligned}
$$

ETF no se solidariza necesariamente con las opiniones expresadas por los autores.

Espacio, Tiempo y Forma, Serie vII está registrada e indexada, entre otros, por los siguientes Repertorios Bibliográficos y Bases de Datos: DICE, ISOC (CINDOC), RESH, IN-RECH, Dialnet, e-spacio, UNED, CIRC, MIAR, FRANCIS, PIO, Ulrich's, SUDOC, 2DB, ERIH (ESF).

\author{
UNIVERSIDAD NACIONAL DE EDUCACIÓN A DISTANCIA \\ Madrid, 2013 \\ SERIE VII · HISTORIA DEL ARTE (NUEVA ÉPOCA) N. ${ }^{\circ} 1,2013$ \\ ISSN $1130-4715 \cdot$ E-ISSN 2340-1478 \\ DEPÓSITO LEGAL \\ $M-21.037-1988$ \\ URL \\ ETF VII · HISTORIA DEL ARTE · http://revistas.uned.es/index.php/ETFVII \\ DISEÑO Y COMPOSICIÓN \\ Ángela Gómez Perea · http://angelagomezperea.com \\ Sandra Romano Martín · http://sandraromano.es \\ Impreso en España · Printed in Spain
}

(c) (1) (8) Esta obra está bajo una licencia Creative Commons

Reconocimiento-NoComercial 4.0 Internacional. 


\title{
EL VACÍO ILUMINADO DEL NEGRO
}

\section{THE ILLUMINATED VOID OF BLACK}

\author{
Alicia Sánchez Ortiz ${ }^{1}$ \\ Recibido: 24/03/2013 - Aprobado: 17/07/2013 \\ http://dx.doi.org/10.5944/etfvii.1.2013.5550
}

\section{Resumen}

Negación y suma de todos los colores, el negro posee una enorme potencialidad que a lo largo de los siglos se ha visto plasmada a través de diversas manifestaciones artísticas, en un lento transcurrir que le ha posibilitado asumir un puesto relevante en el ámbito contemporáneo ${ }^{2}$. La negrura tiene un inmenso abanico de asociaciones negativas y espantosas. Nos remite a los rincones más oscuros de nuestra memoria. Algo lógico teniendo en cuenta su vinculación con la oscuridad y el miedo a lo oculto, a diferencia de lo luminoso, que se relaciona preferentemente con cualidades muy positivas. Cosmogónicamente, la negrura es el caos; ontogénicamente, es el signo de la muerte y la tumba, o del ambivalente útero; es también el color del no ser, del vacío; físicamente connota la ceguera; psicológicamente significa la temible tierra de los sueños y el inconsciente. El negro nos exhorta a mirar la oscuridad, a reconocer la belleza en la ausencia del color y de la luz.

\section{Palabras clave}

color negro; significados simbólicos; iconografía de lo oscuro; lo siniestro; la sombra

\section{Abstract}

Black (disclaimer and sum of all colours) has a large potential that, over the centuries, has been reflected through various art forms which has enabled him to assume an important place in the contemporary scene. The blackness has a huge range of negative and appalling associations. It refers us to the darkest corners of our memory; which makes sense considering its link with the darkness and fear of the occult (in contrast to light, which is associated preferentially with very positive qualities). Cosmogonically, the darkness is chaos. Ontogenetically, is the sign of

\footnotetext{
1. Profesora Titular. Facultad de Bellas Artes, Universidad Complutense de Madrid (alicisan@ucm.es).

2. Las investigaciones sobre los aspectos culturales del color y sus implicaciones simbólicas en el arte apenas han sido objeto de estudio, aunque destacan las aportaciones realizadas por relevantes historiadores como John Gage, Manlio Brusatin o Michel Pastoureau. Todos ellos han puesto de relieve la necesidad de abordar la historia de los colores desde una visión integradora transdisciplinar que tenga en cuenta a los diversos componentes que entran en juego a la hora de definir sus valores, para comprender mejor tanto las mutaciones, desapariciones e innovaciones como las repercusiones que los descubrimientos químicos, técnicos o materiales, han tenido en las
} diferentes épocas. 
death and the grave, or ambivalent uterus. It is also the colour of non-being, emptiness and physically it connotes blindness. Psychologically it signifies the dreaded land of dreams and the unconscious. The black exhorts us to look at the darkness and to recognize beauty in the absence of colour and light.

\section{Keywords}

black colour; symbolic meanings; iconography of the dark; the sinister; the shadow.

FIGURA 1. GEORGIUM AURACH,

PUTREFACTIO F.IV

Pretiosissimum Donum Dei, siglo XVII.

París, Bibliothèque de L'Arsenal,

Ms. 975, f.13-14.

En línea: http://www.herve.delboy. perso.sfr.fr/donum-dei.html\#plancheXIII

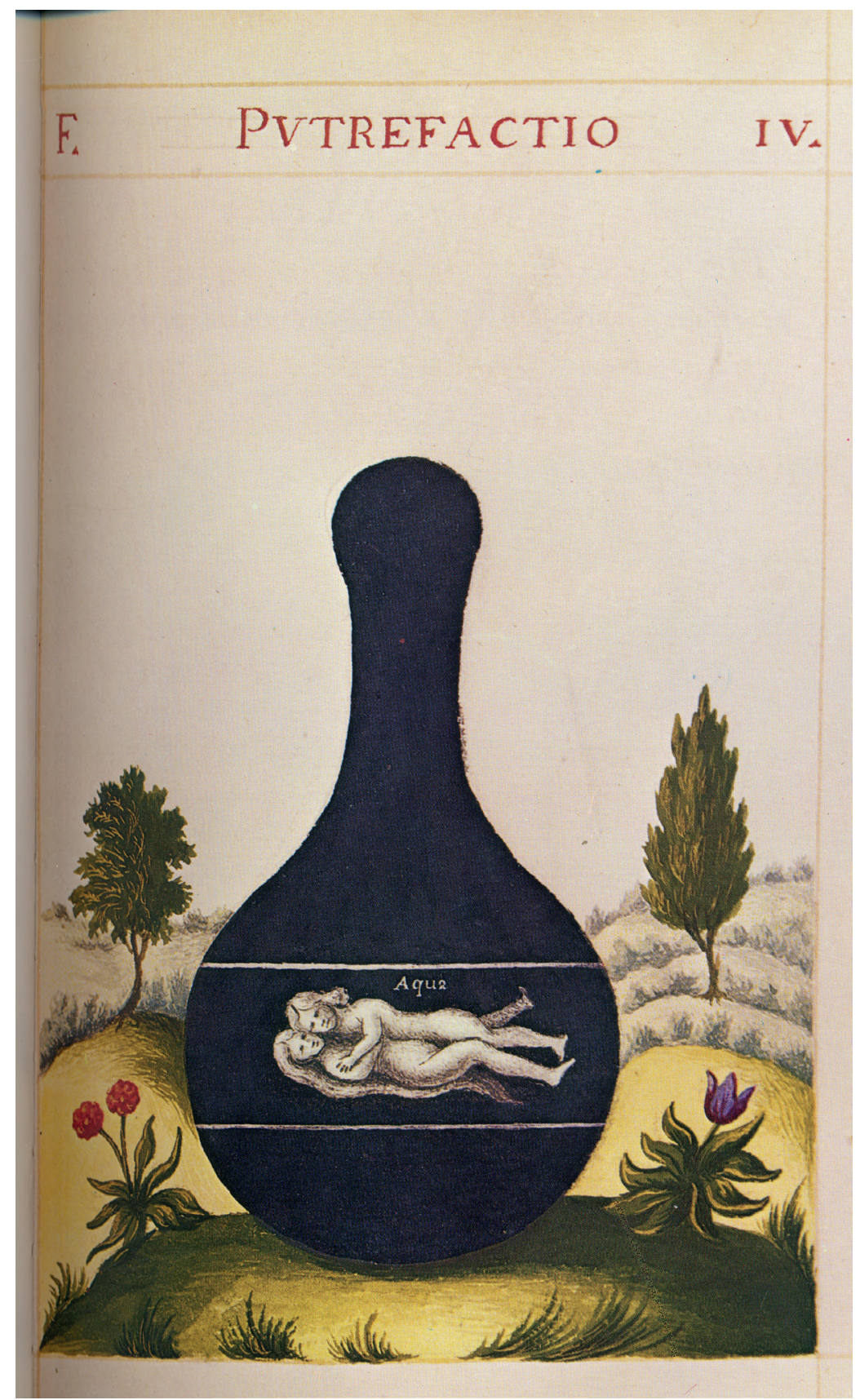

(consulta: 22/03/2013). 


\section{LAS INFINITAS LUCES DEL NEGRO}

Empieza por no ser. El Caos es negro. Negra es la nada. Ni la luz ni las tinieblas pueden concebirse la una sin la otra. En el relato bíblico de la Creación (Génesis I.I-5), el negro precede a todos los otros colores, es el color primordial. En esos primeros momentos, «la tierra no tenía forma y estaba vacía, y las tinieblas pendían sobre la boca del abismo». Ese caos es, en cierto sentido, bueno porque representa la potencia creativa, pero también es malo y hay que trascenderlo, como hacen los alquimistas. Si la luz es buena, las tinieblas, por oposición, no lo son'3. El negro, en consecuencia, es vacío y mortífero. El concepto y el imaginario del Caos juegan un papel particular en el contexto de la alquimia donde el procedimiento seguido por el alquimista para alcanzar la Gran Obra representaba simbólicamente el camino evolutivo del hombre. El Opus alquímico comienza con la mezcla de algunas sustancias que constituyen la denominada materia prima (caos, potencia, sustrato, etc.). Es importante señalar el proceso tenebroso que acompaña al alquimista durante la Obra al negro (FIGURA I). La alquimia relaciona el origen de la piedra perfecta (el lapis non lapis) con el caos de la materia prima, pues sólo desde la putrefacción (nigredo, melanosi o putrefactio) ésta podía perfeccionarse a través del paso por diferentes estados, hasta alcanzar la luz.

Este color, que evoca el mundo antes del nacimiento, que reenvía a una temporalidad donde la oscuridad irradia una luz que trasciende y hace surgir lo que está oculto en lo más profundo de los abismos maternales, se impone como una necesidad de reinventarnos en ese espacio que designa otro campo mental donde la luz se refleja y se ve transformada por el negro. Luz negra como apagamiento revelador. La superficie cubierta por la negrura es el espacio que deben recorrer los ojos entregados a la luz. Al atravesar esa pared nocturna, éstos se cubren de tinieblas y sólo ese silencio ante lo indecible permite un exceso de luz «negras tinieblas fulgurantes de luz» como diría Dionisio Areopagita 4 .

Un mundo dominado por el silencio que Pierre Soulages utiliza para desarrollar una experiencia artística más allá del negro, en lo que él denomina outrenoir. Algunos valores semánticos asociados al negro como la severidad, la austeridad, la radicalidad, la fuerza poderosa de contraste frente a todos los demás colores, lo convierten en el más adecuado para que Soulages construya sus característicos espacios que se diluyen en lo oscuro 5 . Habitante reiterado en las superficies de sus cuadros, este color le ayuda a explorar múltiples efectos ópticos. La luz proviene del secreto del negro y con ella nacen los colores.

A partir de 1979, este artista comienza a desarrollar una práctica mono-pigmentaria extremadamente sutil que, a través de una infinidad de imágenes luminosas,

3. La oposición luz/tinieblas es natural, pero la oposición blanco/negro es totalmente cultural. Véase ELIADE, M.: Le symbolisme des ténèbres dans les religions archaïques. Polarité du symbole. 2. ${ }^{a}$ ed., Bruselas, 1958.

4. Areopagita, D.: Teología mística, 1.1, en Martin Lunas, T.H. (ed.): Obras completas del Pseudo Dionisio A., Madrid, Biblioteca de Autores Cristianos, 1995, p. 371.

5. Sobre Pierre Soulages y su obra remitimos a ENCREVÉ, P.: Soulages. Noir Lumière. París, 1996. De gran interés es igualmente el catálogo de la exposición «Soulages», presentado en el Centro Georges Pompidou, entre el 14 de octubre y el 8 de marzo de 2010. 


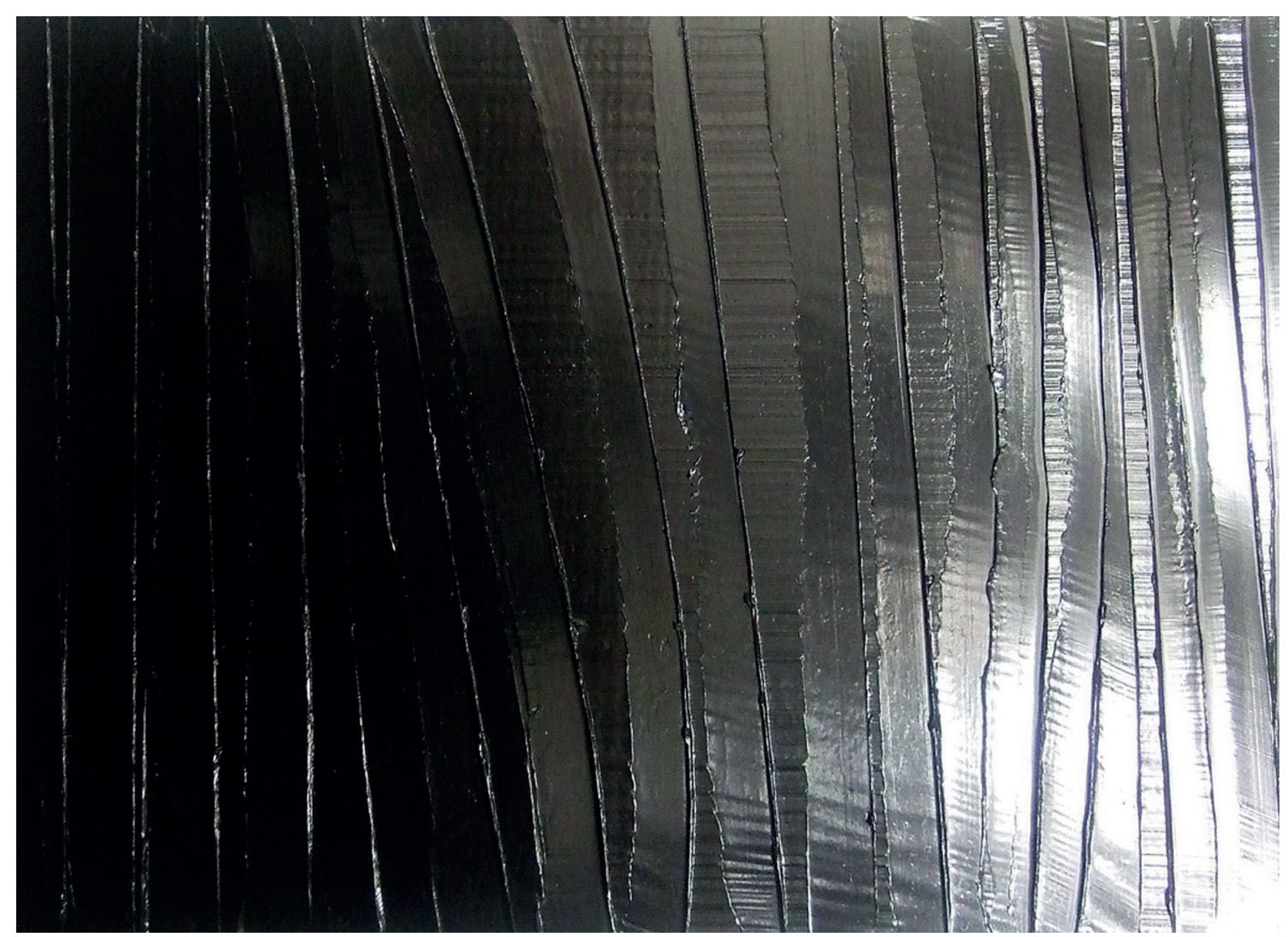

FIGURA 2. DETALLE OBRA PIERRE SOULAGES

Foto: Sergio Calleja. En línea: http://www.flickr.com/photos/scalleja/4775650992/sizes/l/in/photostream/ (consulta: 17/02/2013).

se interpone entre el espectador y la tela. Amplias superficies recubiertas de una pasta espesa y estriada por el paso de la espátula o dejada plana con la ayuda de la brocha (FIGURA 2). Surgen también las masas más o menos diluidas, de negros cálidos o fríos, saturados o mates. Es un negro que expresa un turbulento silencio, una pregunta, una sombra en el pensamiento. Raras veces es una respuesta unívoca.

Las formas terminan por desaparecer bajo un manto cuasi monocromo. Pensemos en la ocupación total del negro en la superficie de los grandes lienzos de Ad Reinhardt, caracterizados por la ausencia de una estructura formal inmediatamente perceptible (FIGURA 3). Rigor como elemento esencial de la concepción de la obra a fin de alcanzar el objetivo último: la eliminación de todo aquello que no sea pintura. Las Blacks Paintings, de formato cuadrado, idénticamente divididas en nueve cuadrados iguales y revestidas de colores negros en los cuales sólo varían los valores tonales de manera casi imperceptible. La extrema reducción alcanzada en ellas a través de sumergir en la oscuridad las formas y los colores, la luz, el espacio y la textura, hasta hacerlos casi irreconocibles, es un recurso que el artista utiliza en un deseo de conseguir plasmar en el lienzo ese vacío dinámico propio del absoluto taoísta-budista. Un vacío que alberga la plenitud del ser. «Ningún símbolo, ninguna imagen, ningún signo», precisa Reinhardt, conocido por sus compañeros 


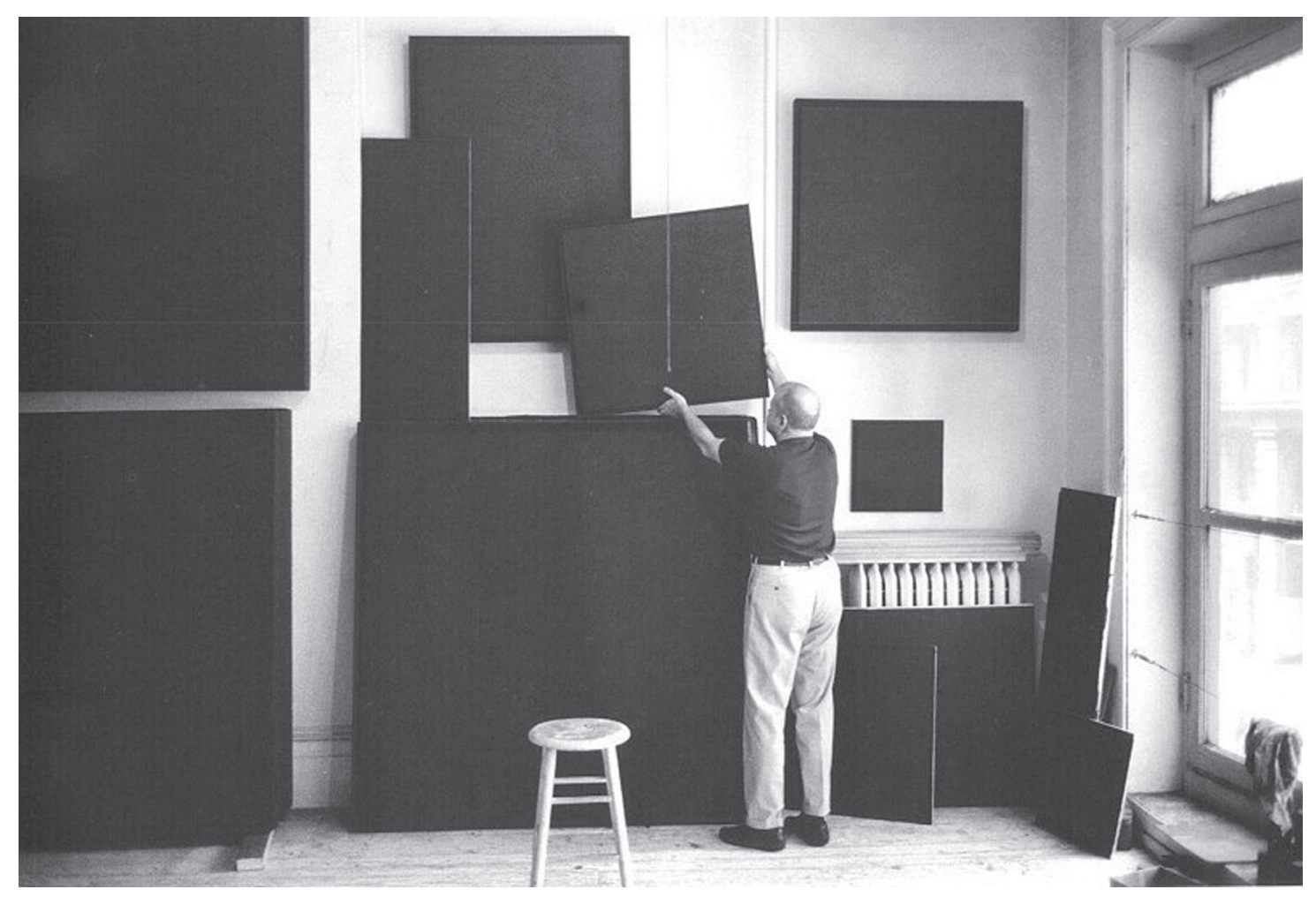

FIGURA 3. AD REINHARDT EN SU ESTUDIO RODEADO DE LA SERIE BLACKS PAINTINGS

En línea: http://minimalissimo.com/2012/10/black-paintings/ (consulta: 14/03/2013).

como el «monje negro». No, a la carga simbólica que el negro ha ido adquiriendo a lo largo de los siglos para de ese modo dejar al espectador penetrar en un universo de ausencia: «La bondad y la maldad se asocian con el negro. En calidad de artista y pintor, yo eliminaría fundamentalmente lo simbólico, porque el negro es interesante no como color, sino como no-color y como la ausencia de color» ${ }^{6}$. Un catálogo de negaciones, diría sobre sus lienzos, «... oscuros (sin luz) colores sin contrastes (incoloros), pinceladas sin pinceladas, una superficie mate, plana, pintada a mano alzada (sin brillo, sin textura, no-lineal, sin borde, ni duro ni blando) que no refleje su entorno puro, abstracto, no objetual, intemporal, sin espacio, quieto» ${ }^{7}$. En definitiva, superficies uniformes donde logra acentuar el significado puramente pictórico de su arte. Al vaciarse de significado representacional, la obra de arte puede adquirir otro significado bien distinto, en el que la ausencia se convierte en lo más importante. Lo esencial es ahora el no estar. Pinturas de silencio, de la restricción,

6. Vv.AA., Monocromos. De Malevich al presente. Catálogo exposición, Museo Nacional Centro de Arte Reina Sofía, Madrid, Documenta Artes y Ciencias Visuales, 2004, p. 179. A Reinhardt le interesa, sobre todo, la negatividad del negro o la oscuridad en la pintura y considera censurable el empleo del mismo como un tipo de cualidad material. Para mayor información remitimos a Rose, B. (ed.): Art as Art. The select writings of Ad Reinhardt (Documents of Twentieth-Century Art). Berkeley/Los Ángeles, University of California Press, 1991, p. 86 y ss.

7. Monocromos..., op.cit., p. 55, nota 28. 


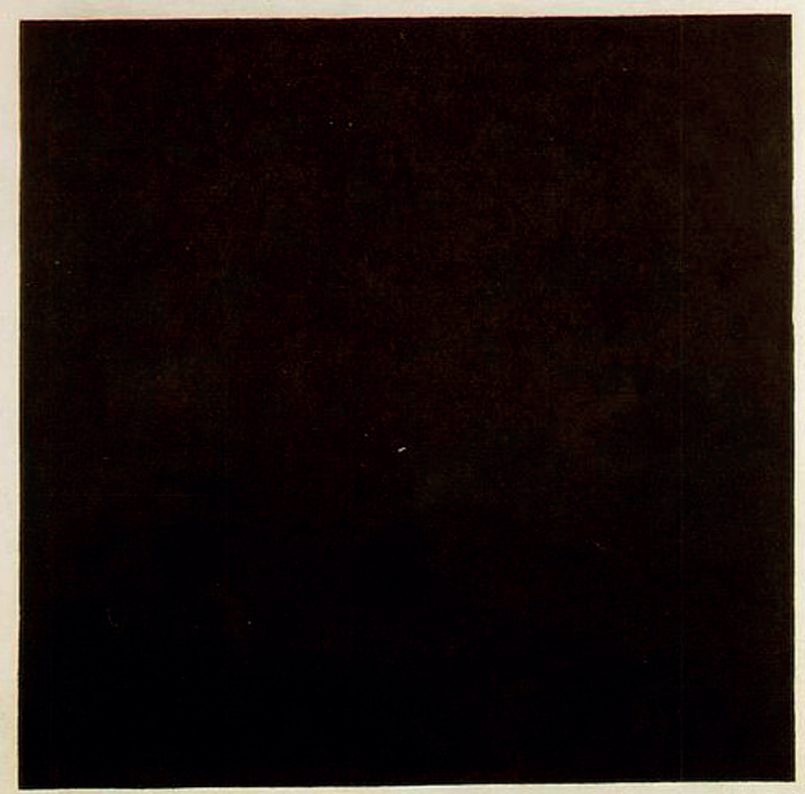

de la ausencia, de la nada que requieren del espectador una larga contemplación para discernir las relaciones tonales de un sinfín de negros que tienen a la luz como cualidad inmanente.

Oscurecer la mirada, bajar la intensidad, es, en opinión de Mercedes Replinger, un ejercicio previo para la visión luminosa ${ }^{8}$. El espectador se deslumbra ante un fogonazo oscuro. Las misteriosas manchas negras que aparecen sobre la pared en Días de Eclipse (I988), de Aleksandr Sokurov, aluden a unos ojos cegados ante el misterio. Esa mancha oscura puede extenderse hasta cubrir por completo la pantalla de proyección. Un ejemplo de ello es Kiarostami, quien también recurre al campo vacío en forma de pantalla casi a oscuras o fundido en negro en algunas de sus películas. Cuando las imágenes se apagan, los ojos habitan en el vacío. Es el ojo de Horus, la pupila negra del dios convertida en emblema del poder generador de la vida. Espacios oscuros, en los que uno pueda detenerse y poco a poco acostumbrarse a esa sensación hasta comenzar a percibir luces. Para James Turrell la imagen vista en sus Darks Space es una nada de color en la oscuridad. Con frecuencia, el acceso a sus instalaciones se presenta como un umbral que el espectador, venciendo el miedo o la inseguridad que le produce la falta de límites espaciales, deberá traspasar para encontrarse a sí mismo en el silencio del vacío propuesto.

8. Replinger, M.: «Sobre un color siniestro», en NeGro. Catálogo exposición. Brasilia, Conjunto Cultural da Caixa, 2002. 
Nada de textura, nada de huellas del pincel o de caligrafía, nada de bosquejos o de dibujo, nada de formas, de colores, de luz, de espacio, de tiempo, de escalas, de movimiento, de objeto, de sujeto o de tema. Cuanta más referencia a alguna cosa haga o contenga la pintura, más se alejará de la pureza del arte. No debe haber tonalidades o degradaciones.

Los colores son un aspecto de las apariencias y, por tanto, son superficiales, distraen de lo fundamental. Son considerados bárbaros e inestables pues escapan al control, deben ser camuflados, es preciso eliminar de la superficie de la tela todo lo que no es

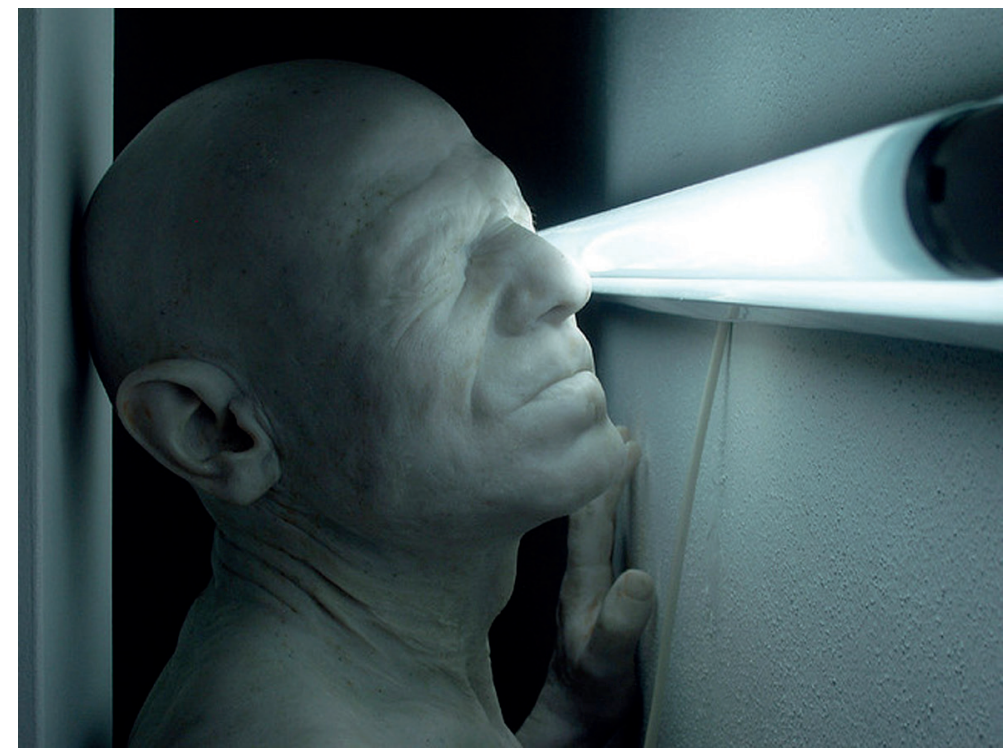

FIGURA 5. BERNARDÍ ROIG, DETALLE DE ACTEON

En línea: http://www.flickr.com/photos/64783355@Noo/119846242/ (consulta: 09/02/2013). pintura. Negro como aquello que permanece físico en la tierra o blanco como aquello que se vuelve idea trascendental. Clara contraposición entre una entidad material y una espiritual. Se trata de encontrar un espacio cósmico donde la inmovilidad quede presente a través de la ausencia, del vacío, de la oscuridad. En sus inicios, la abstracción del arte estuvo estrechamente relacionada con la mística en cuanto a su abandono del mundo de las apariencias en una búsqueda de la espiritualidad interior ${ }^{9}$. Para el mundo occidental es el vacío en el marco blanco, para el Oriente es aquello que ha oscurecido, lo divino-sagrado. En el Cuadrado negro (FIGURA 4), el espacio negro llega a tomar forma, a materializarse. En I9I5, durante la exposición de Petrogrado o.Io, Malevich colgó su obra en la esquina superior de la habitación que tradicionalmente se reservaba en Rusia a los iconos religiosos y manifestó tiempo después: «No era que yo estuviese exhibiendo un lugar vacío, sino el sentimiento de la ausencia del objeto» ${ }^{\mathrm{IO}}$.

Si las densas capas de negro del Cuadrado pueden ser entendidas como un acto de aniquilamiento simbólico, el negro del carbón y la grieta en el craquelado del rectángulo ruso, sugieren a Bernardí Roig la idea de que las imágenes ocultas por aquéllas escapen de su cierre a fin de incorporar otras nuevas (FIGURA 5). Mirar entre la grieta del Cuadrado negro constituye un acto simbólico, un proceso ritual en el que está muy presente la dimensión sagrada. Materializar la ceguera. Encontrar el verdadero color de la ceguera se convierte en un objetivo a alcanzar y para ello

9. Hernández-Navarro, M.A.: «El cero de las formas. El Cuadrado Negro y la reducción de lo visible», Imafronte, n. ${ }^{\circ}$ 19-20, (2007-2008), p.125; VEGA, A.: Zen, mística y abstracción. Ensayos sobre el nihilismo religioso. Madrid, Trota, 2002, p. 35.

10. Cfr. MALevich, K.: The non objetive world. Chicago, Paul Theobald and Co., 1959, p. 68. 
regresa a la metáfora del hombre que se arrancó los ojos para huir de la perturbación del deseo ${ }^{\text {II }}$. Existir sólo a través del negro. El Cuadrado Negro muestra la reducción y supresión de lo visible. El descrédito de lo visual y la desconfianza de la mirada. La pintura es una apariencia, es ciega. Hernández-Navarro considera este cuadro una tachadura; el grado cero no es abstención, sino más bien un tachado o un velo que impide al espectador ver lo que hay detrás de él. Una especie de alegoría de la negación de lo visible ${ }^{\mathrm{i2}}$ que recuerda la evocadora metáfora del Sol cegador de Bataille como fuente de subversión liberadora para el artista. Domina la idea de lo oscuro frente a la epifanía lumínica de la razón ${ }^{13}$. Cuando en I990, con motivo de su restauración, el Cuadrado Negro fue radiografiado, los restauradores descubrieron con sorpresa que bajo la piel negra superficial craquelada se hallaba latente una composición anterior. Esta última capa opaca permitió a Malevich ocultar los elementos formales y cromáticos que previamente había plasmado en el cuadro. En consecuencia, esta obra parece encerrar en sí misma una intencionalidad más cercana a la ocultación que a la reducción; no es tanto un icono desnudo, como una iconostasis «opaca» que impide la visión a modo de barrera que bloquea la mirada.

Ceguera reveladora, ojos ahogados a la espera de una nueva luz que los guíe. Incapacitada para mirar el alma permanece obnubilada por el resplandor de una luz que la turba. Para poder contemplar el Sol y salir de las tinieblas, la mirada tiene que atravesar una pared nocturna. Al silencio formado ante lo indecible - que es al mismo tiempo exceso de luz-, Dionisio Areopagita lo llamó «negro tinieblas, fulgurantes de luz». El sol negro de los místicos es un enceguecimiento por exceso de luz; el de Georges Bataille, la negra luz de Maurice Blanchot o la negrura de los signos de Edmond Jabés, constituyen fulguraciones opacas del relámpago que ilumina y ciega a un tiempo. Oscuridad, hueco y pozo insondable que la tradición simbólica sufí denominaba luz negra, cielo oscuro que anuncia la presencia de lo desconocido. Los místicos utilizan la ceguera como concepto simbólico para señalar el camino a aquéllos que se empeñan en aferrarse a la realidad palpable de su existir. Llama de amor, describe San Juan de la Cruz en su tercera canción «las profundas cavernas del sentido que estaba oscuro y ciego». El obliterar al alma es librarla de todo aquello que pueda desviarla de la realidad suprema. Para Santa Teresa sólo a través de la oscuridad se alcanza al Amado. Es la ascética como camino para llegar al supremo grado de contemplación.

Oscuridad. Viaje nocturno. La noche oscura del alma. La noche mística. El lugar de transformación. Un hombre camina iluminado por un foco en la oscuridad. Se dirige hacia las llamas, se introduce en ellas y las traspasa. A continuación, su cuerpo resurge del fuego, desborda los límites de la pantalla. Surge la oscuridad absoluta. Se ha completado el ciclo de la muerte y la regeneración. De nuevo

11. Roıg, B.: Ejercicios de Reclusión. Catálogo exposición, Monasterio de Veruela, 2005, p. 63. Para ampliar este análisis remitimos a The Light-exercices series. Bernardí Roig. Ministerio de Asuntos Exteriores y de Cooperación/Sociedad Estatal para la Acción Cultural Exterior, 2006. http://www.accioncultural.es/es/publicaciones/bernardi-roig-light-exercises-series (consultada el 14/05/2012).

12. Hernández-Navarro, M.A.: op. cit., pp.137-140.

13. BATAille, G.: La oscuridad no miente. Madrid, Taurus, 2001. 


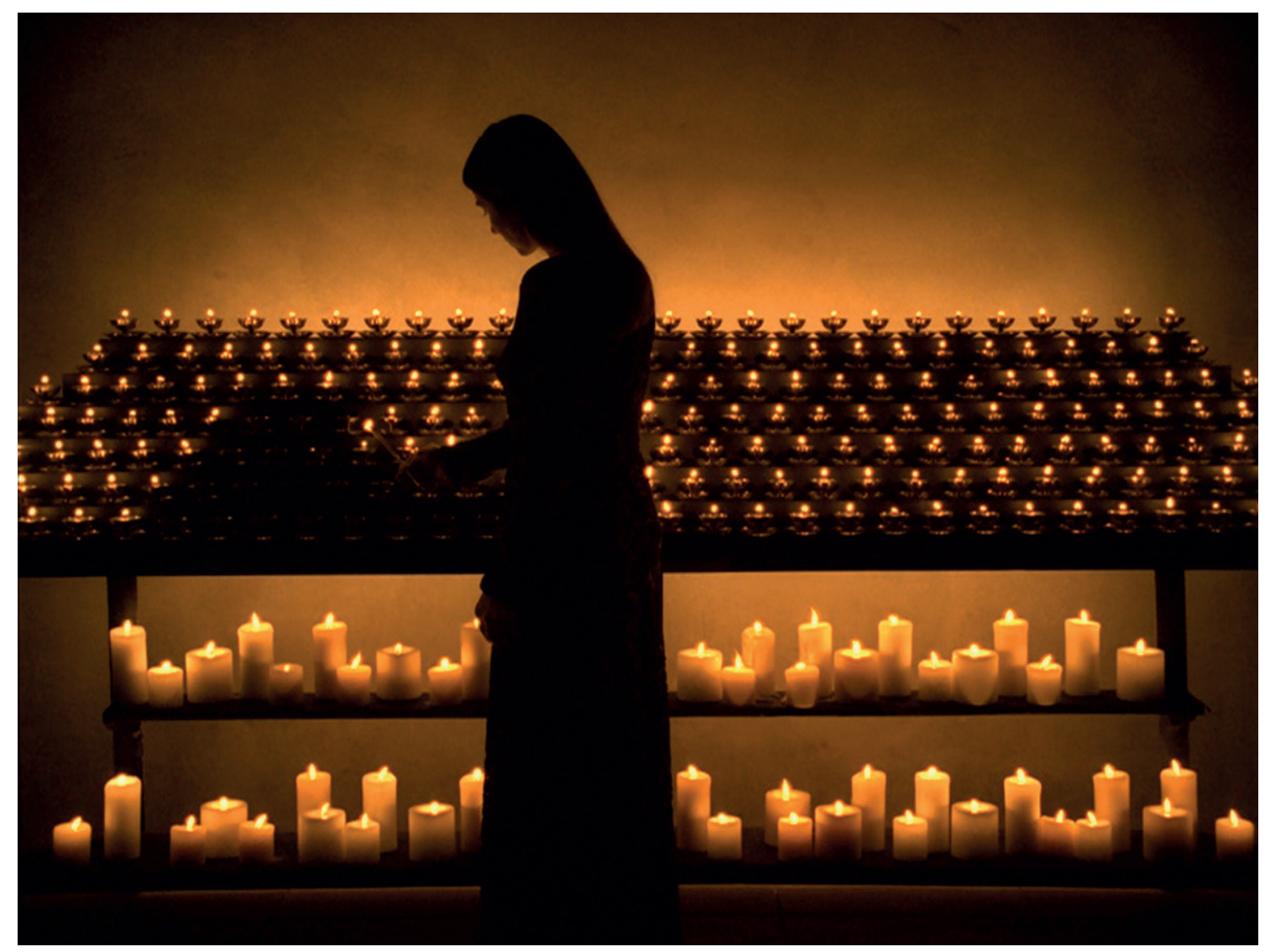

FIGURA 6. BILL VIOLA, VIDEO-INSTALACIÓN TRISTÁN E ISOLDA PARA LA ÓPERA NACIONAL DE PARÍS, 2005 Foto: Kira Perov.

En línea: http://www.flickr.com/photos/canadianoperacompany/6715521673/ (consulta: 03/02/2013).

oscuridad. Brota un punto de luz. Una silueta oscura es envuelta por el resplandor de las llamas. La mujer avanza, se sumerge en la negrura del agua, la traspasa. Sale de la pantalla hasta llenar todo el espacio. Oscuridad absoluta. La entrega del amor a la fuente regeneradora de la muerte ha sido concluida. En Night Journey, de Bill Viola, las imágenes se detienen en el momento en que los cuerpos atraviesan el velo de la muerte, simbolizada por una negrura absoluta; pero no se trata de un corte brusco de la vida, sino del inicio del viaje, un comienzo (FIGURA 6). Refleja un punto en medio de la ópera de Richard Wagner Tristán e Isolda, cuando los amantes se dan cuenta de su destino. La progresión de la imagen representa no sólo un viaje exterior de acción - el acercamiento de Tristán a través de la oscuridad-, a la luz de un fuego flameante, sino también un viaje interior de contemplación -el encendido por parte de Isolda de un grupo de velas-, hasta que la oscuridad de su habitación se llena de luz. A partir de un texto épico, Viola plasma un profundo pathos colectivo actualizado con formas contemporáneas.

La travesía de la vista hacia el fondo de la ceguera, no es sino el desvelamiento de otra luz, la visión que duerme en la noche, bajo el ver «cierra los ojos y ve (...) 
Si los abro y estoy para siempre en lo negro adiáfano», sugiere Joyce en Ulysses ${ }^{\mathrm{I4}}$. Casi al comienzo de Topio stin omichli (Paisaje en la niebla) (I988), película de Theo Angelopoulos, la pantalla permanece completamente a oscuras mientras la voz infantil de Voula, casi susurrada, relata el Génesis a su pequeño hermano Aléxandros: «En el principio había oscuridad y después se hizo la luz... y la luz se separó de la oscuridad».

Una pausa que marca el fin completo, «el sonido interior del negro es como la nada sin posibilidades, la nada muerta tras apagarse el sol, como un silencio eterno sin futuro y sin esperanza», diría Kandinsky al referirse al color negro ${ }^{15}$. Su silencio y su inmovilidad recuerdan el final de la vida. Es difícil expresar mejor aquel vacío primordial en el que se disuelven todas las formas fenoménicas del ser. Noche primordial en la que la mirada de Orfeo contempló a Eurídice, no bajo la luz del día sino en su eterna noche, en la extrañeza de lo siniestro, en el límite de lo bello y ante sus ojos ésta se desvaneció para siempre. Su deseo de ver más allá, incluso aquello que carece de rostro, le lleva a contemplar la propia muerte.

Este tipo de imágenes negras están presentes en la obra de Paul Klee que llega al dibujo como «negativo». Los diarios del pintor registran esa búsqueda, «recuérdese el negro total hecho con luz en los negativos fotográficos» ${ }^{16}$. Se refiere al matiz oscuro de la energía luminosa, una luz seguida por el negro, energía negra, matiz al que llega por medio de la elaboración de los dibujos sobre cristal ennegrecido. Iluminaciones inversas al intentar crear, sobre un cristal ahumado, los signos de un mundo formado por lo que los trazos acotan; los trazos blancos hacen aparecer las formas sobre el espacio negro; de nuevo nos encontramos ante el emergente negro, la epifanía de lo oscuro. Sólo se accede a la luz desde el negro. Luz negra, lo invisible apercibido ocultamente.

\section{LA OSCURIDAD ABISMAL}

Como si nos introdujésemos en un espacio sagrado, los grandes lienzos con sus colores que Rothko pinta al final de su vida se abren a modo de ventanas y después se cierran como velos corridos $^{17}$ sobre el vacío a fin de permitir al ojo que se pierda en sus propios pensamientos. Ver el negro simplemente como ausencia es cerrar la vista a la mera percepción. Pero si uno mira fijamente la superficie de estos cuadros negros puede observar que hay modulación y que, a través de ella y de los matices cromáticos, emergen diferentes formas, intensidades y tonos que casi brillan con una luz interna. Situarse ante ellos es algo así como moverse en medio de la noche, unas veces rodeado de sombras que parecen abrirse para dejar espacio a su alrededor y otras envuelto en la más completa negritud.

14. JOYCE, J.: Ulysse. Barcelona, Lumen, 1976, vol. I, pp. 116-117.

15. KANDinsky, W.: De lo espiritual en el arte. México, Premia Editora, 1989, pp. 73-74.

16. KLEE, P.: Diarios 1898-1918. Madrid, Alianza, 1987, p. 197.

17. Hernández-Navarro se refiere a esta estrategia de la anti-visibilidad cuando analiza el Cuadrado Negro de Malevich. Véase HernÁNDEZ-NAVArRo, M.A.: op. cit., p. 140. 
Quizás este artista quiso con sus juegos velados hacer visible la oscuridad del ser. Él mismo manifestó su necesidad de plasmar en sus obras la preocupación por la muerte a través de los recursos plásticos del espacio y del color. En opinión de Amador Vega, las pinturas de Rothko mantienen un equilibrio entre oscuridad y claridad ${ }^{18}$. La complementariedad de esos dos mundos, lo visible y lo invisible, quedan supeditados al dramatismo cromático que este artista otorga a lo que él mismo llamaba «retratos o estados del alma», grandes superficies de lienzo que se muestran como lugares de una intensa intimidad ${ }^{19}$, negros que enfrentan al espectador a sí mismo en un viaje que se inicia por medio de la contemplación y que lleva a alcanzar la existencia, no sin antes pasar por el abismo del vacío.

De nuevo nos situamos ante la tiniebla mística, un espacio donde la oscuridad invade el vacío y se extiende como una idea que preludia los orígenes de la creación pero a la vez también la propia destrucción del ser. Creador de la oscuridad, del desierto y del vacío en su personal búsqueda hacia la divinidad, Rothko experimentó el trayecto religioso como un camino de retorno a la unidad primigenia de la que todo ha surgido ${ }^{20}$. Poco a poco, sus «paisajes del abismo», resultantes de aquella Serie negra, realizada para la Capilla de Houston, fueron llenándose de sombras, desde el pardo al negro opaco hasta alcanzar un negro absoluto monocromo (como el estado de nigredo de la Gran Obra), preludio de su muerte. Como una especie de agujeros negros, estas obras invitan al espectador a cruzar el umbral, a perderse en las profundidades del precipicio. El fuerte componente opresivo existente en ellas ha hecho que algunos las hayan considerado una especie de horizonte insoportable de la vida, donde el mundo entero se ha consumido y lo único que queda es el vacío. El rojo apasionado de los tiempos felices se tiñe con el negro siniestro de la depresión.

Los lugares en tinieblas son ámbitos de sufrimiento y de dolor, inquietantes y peligrosos, siempre habitados por seres monstruosos. Platón se refiere a la caverna (República 7) como un lugar de dolor y de castigo donde las almas humanas están encerradas y permanecen encadenadas por los dioses. Sobre un muro se proyecta un espectáculo de sombras que simbolizan el mundo engañoso de las apariencias; éstas deben salir de la caverna para contemplar el mundo verdadero, el de las Ideas. Lejos de ser fuente de vida o de energía, lo es de oscuridad y de tortura. Alrededor del mito de la caverna se han ido condensando los cánones por los que se ha regido durante milenios la presencia negativa: falsedad, negatividad, mortandad. El mundo de los vivos se transforma en recuerdo del mundo de los muertos. De igual modo, en el Fedón, los infiernos están destinados al castigo de los culpables y son el reino

18. Vega Esquerra, A.: Sacrificio y creación en la pintura de Rothko. Madrid, Siruela, 2010, p. 44.

19. Ibidem, pp. 90-91.

20. Amador Vega relaciona la abstracción de Rothko con algunas concepciones de la teología negativa y atribuye a los trípticos de Houston una doble cualidad, táctil y visual, mediante la cual el artista consiguió desvelar el mundo de las apariencias y el de las esencias. Este investigador vincula las transformaciones morfológicas del artista con los procesos rituales de la religión arcaica. Remitimos de nuevo a Vega Esquerra, A.: op. cit. p. 101. Se considera también de interés la consulta de la tesis doctoral LUCA DE TENA NAVARRO, M.: La presencia de lo ausente. El concepto y la expresión del vacío en los textos de los pintores contemporáneos occidentales. Salamanca, Universidad de Salamanca, Facultad de Bellas Artes, 2008. 
de los muertos, cuya cualidad esencial es la nocturnidad. La llama que quema los rostros, los ojos, las bocas o la cabeza de las esculturas de Bernardí Roig se dirige hacia una visión interior. Imposibilitados para el habla o la visión, sus hombres de negro nos conducen hacia el mundo platónico de las ideas y también a la cultura religiosa del catolicismo, impregnada por la culpa. Figuras de reclusión, castigo y muerte insisten en esa idea. Quizás no sea casualidad el hecho de que los pintores tradicionalmente hayan obtenido las tonalidades oscuras mediante la fabricación de un compuesto hecho a base de moler huesos y materias orgánicas, como si la representación de las sombras no pudiera hacerse más que poniendo en acción la propia presencia de la muerte.

En I745 se publican por primera vez las Carceri d'invenzione (Prisiones Imaginarias) de Piranesi (I720-I778), fechadas en I742, y en I76I, sale a la luz una segunda versión compuesta por dieciséis láminas, caracterizada por una mayor oscuridad. Por entonces eran ya famosas y temidas las Piombi (Cárceles de los Plomos) que inmortalizaría Casanova en sus memorias. Espacios del alma más que mera arquitectura, las cárceles que nos muestran estos grabados son lugares oscuros, claustrofóbicos, angustiosos. Los grises y negros con los que reconstruye estos ámbitos pesan en el alma como plomo en el corazón y la tristeza que produce su contemplación es insondable (FIGURA 7). Son espacios dignos del Infierno dantesco, ubicados en algún

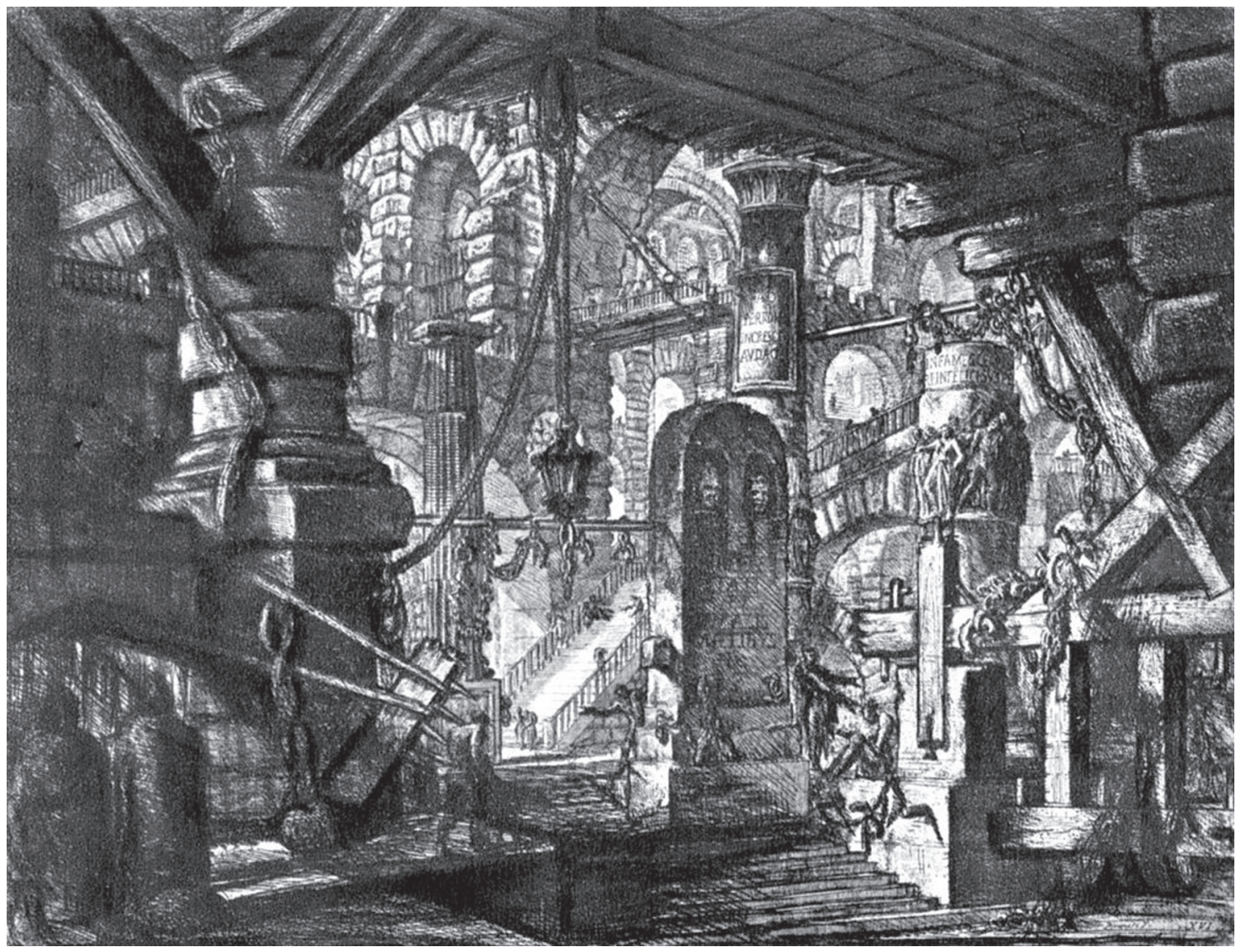

FIGURA 7. GIOVANNI BATTISTA PIRANESI, MUELLE DE EMBARQUE CON CADENAS

Plancha XVI de la serie Prisiones Imaginarias (Le Carceri d'Invenzione), aguafuerte. Roma, edición de 1761. En línea: http://commons.wikimedia.org/wiki/File:Piranesio2.jpg (consulta: 22/03/2013). 
lugar donde la ausencia de aire, asfixia y confunde a sus desgraciados moradores. A través de la iluminación, Piranesi consigue crear un mundo subterráneo e infernal, sobrecogedor, un espacio donde domina el caos y la muerte ${ }^{21}$.

Numerosos poetas cantaron a la noche como la madre de los dioses y de los hombres, origen de todas las cosas creadas, pero no pudieron evitar el pánico que provocaba, miedos que vienen de lejos, probablemente de las épocas en las que aún no se había descubierto ni el fuego ni la luz. Las tinieblas cósmicas (zophos) constituyen un espacio lúgubre. El más allá era un reino tenebroso, sin retorno, al que sólo a los héroes les estaba permitido visitar. El Tártaro estaba situado en el límite del mundo, como cuenta Homero en la Ilíada, o en las entrañas de la Tierra, como narra Hesíodo en su Teogonía. Rodeado por ríos infernales, este imperio oscuro solía ser pintado como un paisaje rocoso, ácido y caótico donde la luz no tenía cabida. Aquel Infierno homérico fue después tomado por los romanos que lo concibieron como un ámbito oscuro donde vagaban las sombras de los muertos.

El negro, color material, cerrado en sí mismo, incapaz de evolucionar, puede en su simbolismo representar la fuerza de disolución y disgregación. Ausencia de color. Lo oculto. El silencio. Lo negro en la pintura de Gustavo Acosta conlleva una especie de espiritualidad y recuerda, una vez más, la propiedad de dicho color para provocar movimientos lentos y apagados en la percepción que tenemos del mundo que nos rodea, hasta tal extremo que es capaz de inmovilizarnos y

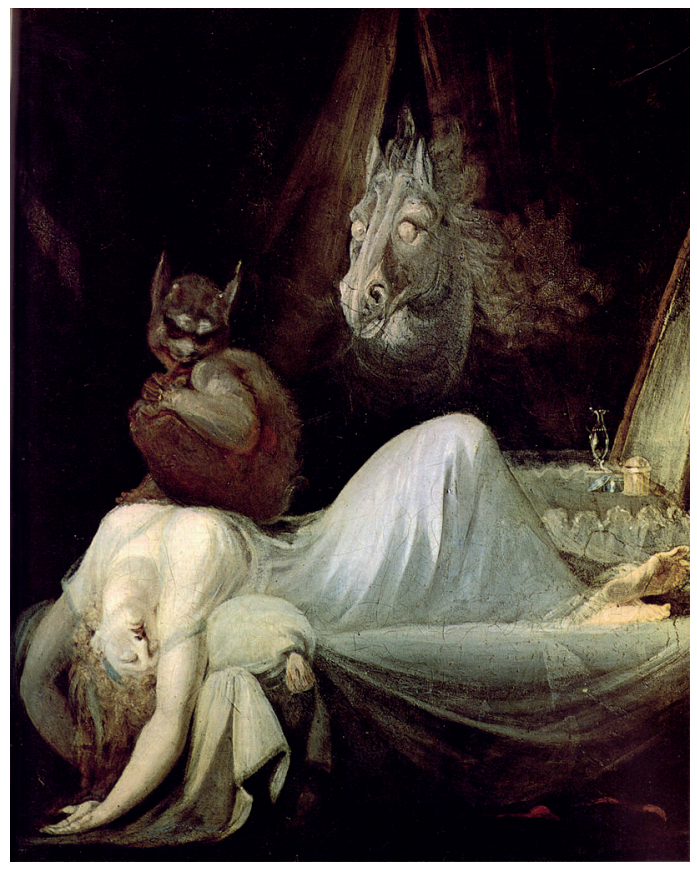

FIGURA 8. JOHANN HËNRICH FÜSSLI, EL ÍNCUBO O LA PESADILLA, 1802

Óleo sobre lienzo. Freies Deutsche Hochstift, Goethemuseum. Foto: The Yorck Project. En línea: http://commons.wikimedia.org/wiki/ File:Johann_Heinrich_F\%C3\%BCssli_053.jpg?uselang=es (consulta: 22/03/2013). concentrarnos en nuestro yo más íntimo. La ausencia premeditada de cualquier referencia al ser humano, la extraordinaria monumentalidad de las formas, la mortecina luminosidad que sirve para lograr una atmósfera ciertamente opresiva, se unen para construir su peculiar universo pictórico.

El sueño deja al ser humano a merced de los peligros de la noche donde habitan los seres más monstruosos. Es un estado frágil en el que el durmiente inconsciente puede ser víctima de un ataque de espíritus malignos. La obra de Johann Hënrich Füssli, titulada El íncubo o La Pesadilla, cuando fue expuesta por primera vez, en I782, provocó una gran sensación entre los espectadores que se quedaron perplejos ante la visión que el artista había recreado (FIGURA 8). Su pintura le consagró como el pintor de lo extraño y de lo sobrenatural. Con el negro afluyen los seres y

21. Para comprender mejor el pensamiento de Piranesi y la estética de sus Cárceles o Prisiones Imaginarias, es esencial la lectura de la obra de YourCenar, M.: A Beneficio del Inventario, y en concreto el cuarto ensayo que le dedica a este artista con título «El negro cerebro de Piranesi». Madrid, Alfaguara, 1987, pp. 111-156. 
las cosas pertenecientes a un universo sobrenatural fascinante. Se alza como paraíso de la fantasmagoría. Todo reposa sobre el negro. El mundo de los sueños creado por Odilon Redon es, ante todo, negro. Todos los animales que vienen a inquietar sus noches (la araña, el cuervo), los seres mágicos tienen la sustancia y la fuerza evocadora del negro. La noche oscura entendida como momento en el que los seres abominables aprovechan para atacar a sus presas, simboliza el caos y la muerte ${ }^{22}$.

\section{ALTER EGO}

Definida como la «proyección oscura que un cuerpo lanza en el espacio en dirección opuesta a aquella por donde viene la luz», o el «espectro o aparición vaga y fantástica de una persona ausente o difunta», la sombra es considerada una propagación del objeto que la proyecta. Este segundo yo transparente del individuo es idéntico a su alma o fuerza vital. El fenómeno de la sombra del propio cuerpo que acompaña silenciosa a la persona en su caminar, ha generado fascinación desde siempre y ha sido una constante fuente de inspiración para el desarrollo de la creatividad en los artistas ${ }^{23}$. Así lo demuestran las numerosas fábulas y leyendas populares que cuentan antiguas historias sobre cómo la sombra es capaz de alargarse y empequeñecerse, ligada a acontecimientos de carácter mágico y, en ocasiones, a relatos de tipo mitológico. Quizás la más famosa sea la historia de Peter Pan, cuyo pequeño protagonista pierde su propia sombra y cuando consigue recuperarla la ata a su cuerpo, primero con un poco de jabón y después reduciéndola y estirándola. Este inquietante ejercicio de cambio de tamaño ha constituido un material esencial para los poetas del romanticismo alemán, hasta el punto de convertirla en protagonista, arquetipo y símbolo de toda una época. A menudo, la sombra está vinculada con miedos ancestrales y culturales. Algunas leyendas cuentan la pérdida de ésta si el hombre vendía su alma al diablo. El cuento de H.C. Andersen es un buen ejemplo de ello: un joven filósofo de un país del norte pierde su sombra mientras visita el sur de Italia. La sombra se vuelve autónoma, se convierte en una persona y termina invirtiendo los papeles, de modo que el poeta se vuelve la sombra de su propia sombra.

Cuenta Plinio el Viejo que un día una joven enamorada trazó el contorno de la sombra de su amante sobre una pared y que fue así como los hombres descubrieron la pintura. A partir de entonces la historia de la sombra en el arte occidental no ha dejado de ser una constante emancipación. La valoración de ésta en

22. De extraordinario interés para profundizar más sobre el tema que nos ocupa puede resultar la consulta del catálogo elaborado con motivo de la sugerente exposición temporal organizada por el Musée d'Orsay de París bajo el título L'ange du bizarre. Le romantisme noir de Goya à Marx Ernst, aludiendo a un cuento fantástico que Edgar Allan Poe publicó en 1850. Con una cuidada selección de doscientas obras, esta muestra disecciona la vertiente del romanticismo y rastrea a través de sus tres épocas características, su nacimiento (entre 1770-1850), las mutaciones simbolistas (de 1850 a 1900) y su redescubrimiento de la mano del Surrealismo (principios del siglo xxı), el recorrido en la historia del arte de lo que se ha denominado «lado oscuro», como concepto opuesto al racionalismo que caracterizó el periodo de la llustración.

23. StoichitA, V.J.: Breve Historia de la Sombra. Madrid, Siruela, 2006. 
sus cualidades negativas tuvo su momento en el siglo xvill, coincidiendo con el nacimiento del concepto estético de lo «sublime»; fue así como apareció una verdadera «estética de lo siniestro» (Figura 9). Durante este momento histórico, las linternas mágicas no cesaron de fascinar y la óptica conoció perfeccionamientos considerables. En la década de I770, François Seraphin produjo lo que llamó «Teatro de las sombras», usando una linterna mágica. Por su parte, Étienne-Gaspar Robertson creó «Fantasmagorie» mediante el empleo de un proyector Fantascope, presentándolo por primera vez en el Pavillon de L'Echiquier, en París. Tanto las linternas como las cajas de perspectiva ofrecían diversión variada al público que asistía perplejo a las representaciones. Bajo el nombre de Fantasmagorías pretendían mostrar ante sus ojos una presencia fantasmal que, tras un breve instante de aparición, se esfumaba misteriosamente $e^{24}$. Sombras bailando y aterradores efectos teatrales no dejaban de asombrar a las multitudes. Estos eventos interactivos constituyeron una forma de arte única puesto que a la vez que entretenía generaba un especio para pensar en otro mundo, en el más allá. Una tendencia similar se observa en algunos artistas contemporáneos que crean imágenes fantasmales como un medio para reflexionar sobre las nociones de ausencia y pérdida, utilizando efectos espectrales y medios inmateriales, como sombras, niebla, etc.

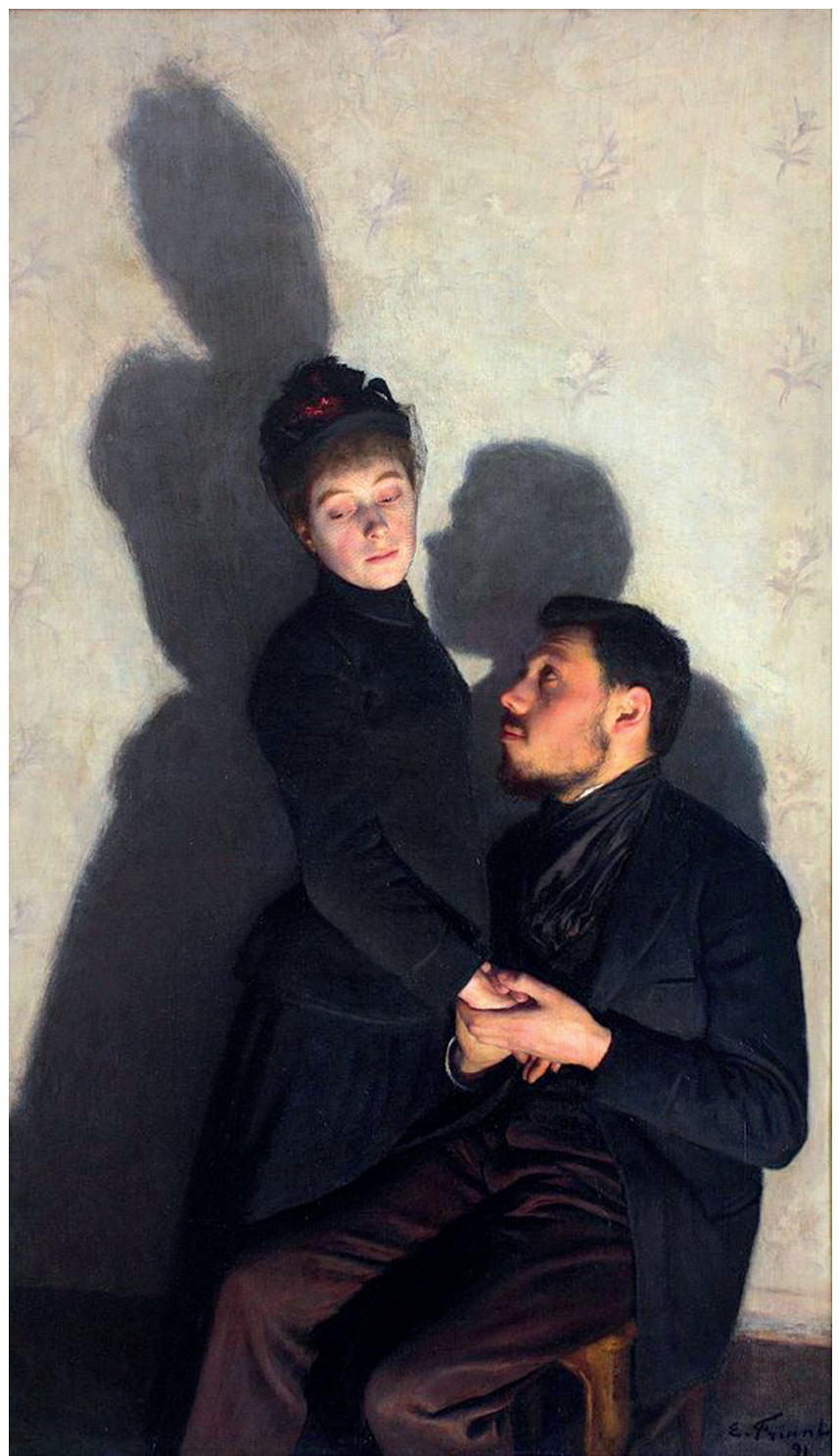

FIGURA 9. ÉMILE FRIANT, SOMBRAS MARCADAS, 1891

Óleo sobre lienzo. Musée d'Orsay, París. Foto: Ondra Havala. En línea: http://commons.wikimedia.org/wiki/File:Emile_Friant_Ombres_ port\%C3\%Ages_1891.jpg (consulta: 22/03/2013).

24. La referencia más antigua de lo que posteriormente se conoció como Linterna mágica se encuentra en el tratado veneciano Liber Instrumentorum. Para una información más amplia remitimos a la exposición comisariada por José Ignacio Roca, Phantasmagoria: Espectros de Ausencia, exposición de Arte Contemporáneo, del 7 de marzo al 21 de mayo de 2007, Sala de Exposiciones temporales del Museo del Banco de la República, Bogotá. Muchas de las obras presentes en la muestra recurren a la sombra para aludir a la muerte, lo oscuro, lo innombrable, así como a la construcción de alegorías referidas a la pérdida y a la desaparición. Sobre este tema resulta de enorme interés la consulta de Warner, M.: Phantasmagoria. Spirit Visions, Metaphors, and Media into the Twenty-first Century. Nueva York, Oxford University Press, 2006. 
Conocido como el «artista de las sombras» (FIgurA Io), Christian Boltanski muestra una preocupación constante por el reino de la oscuridad, siendo recurrente el tema de la muerte y su relación con el recuerdo, tal y como se puede observar en bastantes de sus fotografías donde un momento del pasado que se fue para siempre queda capturado en su mortandad. En Las Concesiones, el negro es el color de la oscuridad. La instalación está compuesta por fotografías de rostros, en blanco y negro, que se proyectan en el centro de la sala sobre paneles de tela traslúcida iluminados desde su interior con luz fluorescente. Todos los retratos son de víctimas y de criminales, en alusión a los significados de devastación, ruina, destrucción y vaciamiento. No hay referencias a su identidad. En las paredes que rodean estos artefactos están colgadas fotografías de cuerpos mutilados, cubiertas por completo con cortinas de paño negro, que el visitante puede elegir correr. Docenas de paños aparecen colgados a diferentes alturas en una pared. Un ventilador de techo se encarga de provocar un constante movimiento de los mismos que permite al espectador intuir la presencia de algo oculto tras ellos. En una especie de ritual contra el olvido, aquel velo negro deja visible fotografías de cadáveres mutilados que causan una respuesta inmediata ante quien es capaz de correr la cortina. En referencia a esta decisión, el propio artista manifestó: «Siempre existe la tentación de mirarlas [a estas fotografías] sabiendo que ellas son malas u horribles. Entonces si miras detrás de la cortina, sabes que estás haciendo algo prohibido. Yo adoro mirar imágenes terribles; yo también soy un criminal. Estoy fascinado con el hecho de morir. Hay una parte muy oscura de mi vida y mi trabajo. No soy sólo un lamento, soy un asesino».

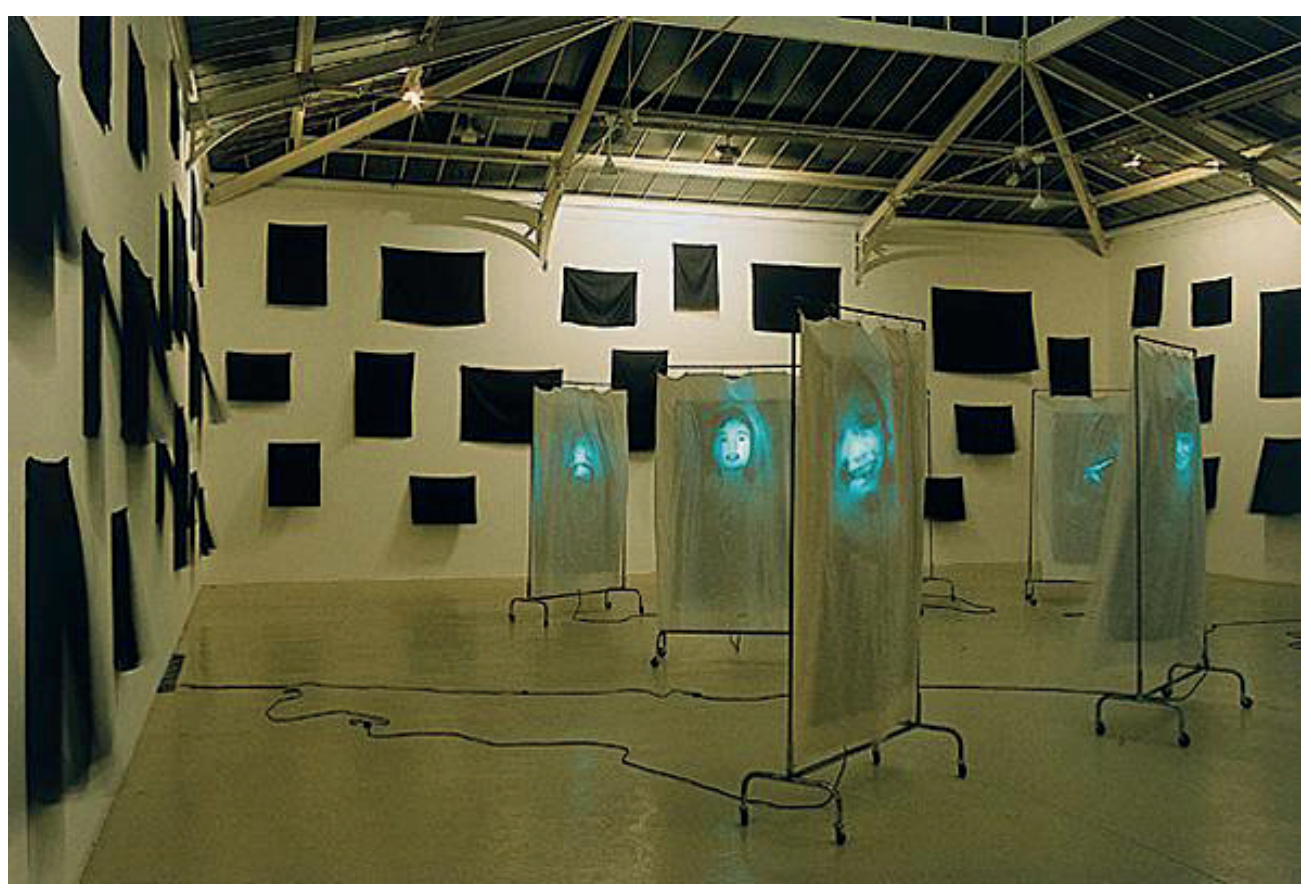

FIGURA 10. CHRISTIAN BOLTANSKI, LES CONCESSIONS

Vista de la Instalación, 1996. Galerie Yvon Lambert, París. Fotografía (c) J.C. Mazur/Documentation du MNAM-CCI. En línea: http://www.larousse.fr/encyclopedie/image/Laroussefr_-_Article/1008606 (consulta: 22/03/2013). 
Las sombras y proyecciones nos conducen por el curso del tiempo y de la experiencia humana. En un viaje hacia el fondo de nosotros mismos para retornar al origen, es necesario transitar desde el reflejo cegador a fin de alcanzar la auténtica luz, aquella que se encuentra en la sombra, en el seno de la oscuridad. Eulalia Valldosera destaca como una de las artistas con una propuesta plástica más interesante al respecto. Muchas de sus obras precisan de esa noche para que las proyecciones puedan apreciarse y sólo al atravesar la luz artificial, podemos una vez abandonado el ámbito diurno del conocimiento, llegar al fondo oscuro de nuestro inconsciente (el material no iluminado). La sombra es, en consecuencia, aquella parte que no vemos pero que siempre nos acompaña, es todo aquello que tendemos a negar y que, sin embargo, proyectamos reflejado en el otro (FIGURA II).

\section{LA NEGACIÓN DEL NEGRO}

Negativo y siniestro, el negro ha cargado con todas las culpas y tinieblas del mundo. De igual modo, la obra de arte verdadera debía ser negra puesto que lleva sobre sus espaldas la pesada carga de dolor y miseria del ser humano. Es en el fragmento de la Teoría estética titulado «El ideal de lo negro», en donde se articula uno de los aspectos más importantes del pensamien-

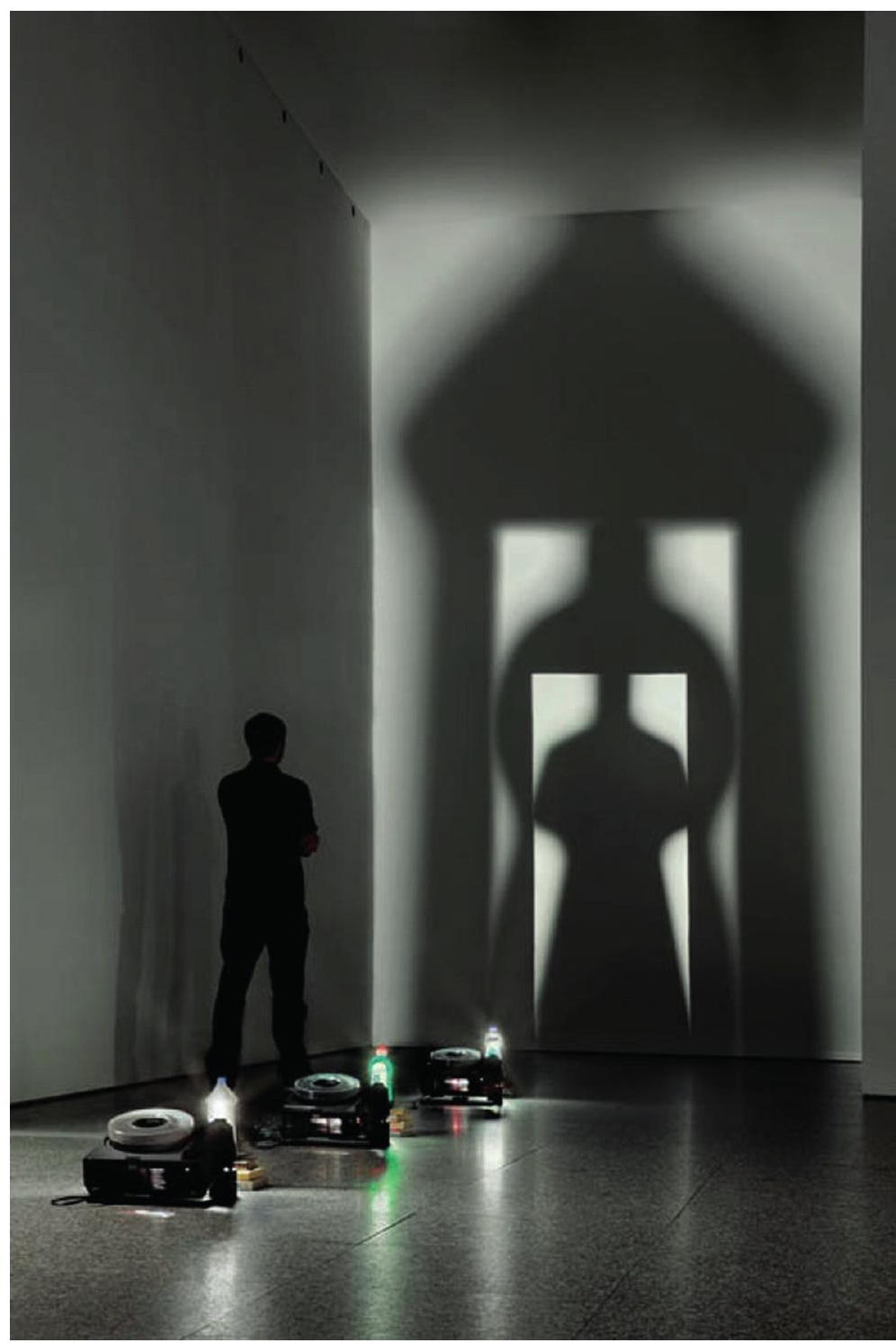

FIGURA 11. EULÁLIA VALLDOSERA, ENVASES: EL CULTO A LA MADRE, 1996 Colección mACBA. Fundación mACBA. Donación del Taller de la Fundació. En línea: http://www.macba.cat/es/envasos-el-culte-a-lamare-1543 (consulta: 23/02/2013). to estético de Adorno. Afirmación de lo negro como ideal de todo arte que quiere ser autónomo, y negación del negro por su contrario, los colores, en la producción deificada de la industria cultural. En tanto que imagen, las implicaciones semánticas del negro superan el contenido simplemente denotativo para aproximarse a nociones como lo oscuro, lo tenebroso, lo sombrío, lo no familiar, la disolución y la disonancia. También es símbolo de melancolía, la desgracia, la tristeza ${ }^{25}$, siempre en relación a un malestar social. Sus

25. Marulanda, V.: «La metáfora de lo negro: una aproximación a la estética de T.W. Adorno», en Ideas y 
reflexiones se sitúan en un momento histórico, el de la sociedad industrial avanzada, que mira hacia la modernidad y que pregunta ¿para qué arte en tiempo de miseria? La sentencia de Adorno es contundente «escribir un poema después de Auschwitz es un acto de barbarie» ${ }^{26}$.

La negación radical es la única salida correcta. Lo negativo, imagen de lo negro, es la condición de las obras auténticas ${ }^{27}$. El negro es el símbolo del ascetismo total que proclama Adorno para el arte autónomo, ascético en cuanto despojado del goce y del ideal de lo bello. El Modernismo asociado a la desgracia fue por primera vez presentado de la mano de Baudelaire, quien lo envuelve en un halo maldito «lo nuevo es hermano de la muerte». El arte, por tanto, no salva nada ni a nadie, el arte abre heridas. Y si hay un aura para las obras de arte, ésta debería ser negra por todo el absurdo del mundo. En la música, el dodecafonismo, creación de A. Schönberg, encuentra Adorno la fórmula más perfecta de esa autonomía ${ }^{28}$, su rebelión contra la tonalidad y su renuncia a los alardes sonoros, su preferencia por las combinaciones instrumentales reducidas, su disposición hacia la interioridad y la reflexión, los tonos menores y, en definitiva, su referencia a la oscuridad. Negro absoluto, desgarrado y angustioso el que utiliza Joseph Beuys en Sobresalto en la noche (Hombre en la tumba), dibujo de $1962^{29}$. Con motivo de la exposición Schwarz (Negro), celebrada en octubre de i98I en la Kunsthalle de Dusseldorf, presentó su obra Schwarzes Loch (Agujero negro). En la pared de la sala perforó un agujero para posteriormente colocar un tubo de estufa pintado de negro. Con él invitaba al espectador a mirarse hacia dentro de sí mismo, adentrándose en el interior oscuro del psiquismo.

En un sentido parecido, el negro está omnipresente en los cuadros de Anselm Kiefer (Donaueschingen, I945) de los años I970-I980. Aquí el artista conjuga la memoria de la Alemania nazi y la angustia provocada por el Holocausto con las visiones místicas extraídas de la religión hebraica. El negro se impone tanto por su valor simbólico como por su poder negativo, irradiando una extraña belleza. Toda su obra está dominada por la oscuridad y especialmente por el no-color negro, utilizado a modo de metáfora de la Alemania después del Nazismo (FIGURA I2). Sus creaciones pueden ser consideradas un espejo donde ver la historia sin memoria.

La linealidad de la vida truncada por la muerte, con un principio y un fin arraigados en el yo, deviene para el ser una imagen analógica del Tiempo. Con el fin de investigar sobre la maleabilidad plástica del espacio y explorar los límites de la percepción lumínica, James Turrell concibió una obra en el tiempo, Roden Crater. Se trata de un espacio excavado en el interior de un cráter que recibe la luz exterior,

Valores, 76-77 (1988), p. 89. En línea http://www.revistas.unal.edu.co/index.php/idval/article/view/21755 (consulta el 10/05/2012); Véase también GutiÉrRez Pozo, A.: «Utopía en negro. El color negro en la estética negativa de Adorno y el Arte Radical Contemporáneo», en Variaciones sobre el color, Universidad de Sevilla, 2007, pp. 187-208.

26. MARULANDA, V.: op.cit., p. 91.

27. Adorno, T.W.: Teoría Estética. Madrid, Taurus, p. 60.

28. Adorno, T.W.: Philosophie de la nouvelle musique. París, Gallimard, 1979, p.142: «... Ha cargado con todas las culpas y tinieblas del mundo; toda su felicidad está en reconocer su infidelidad; toda su belleza en sustraerse a la apariencia de lo bello».

29. Bérnardez, C.: Joseph Beuys. Guipúzcoa, Nerea, 1999, p. 52. 


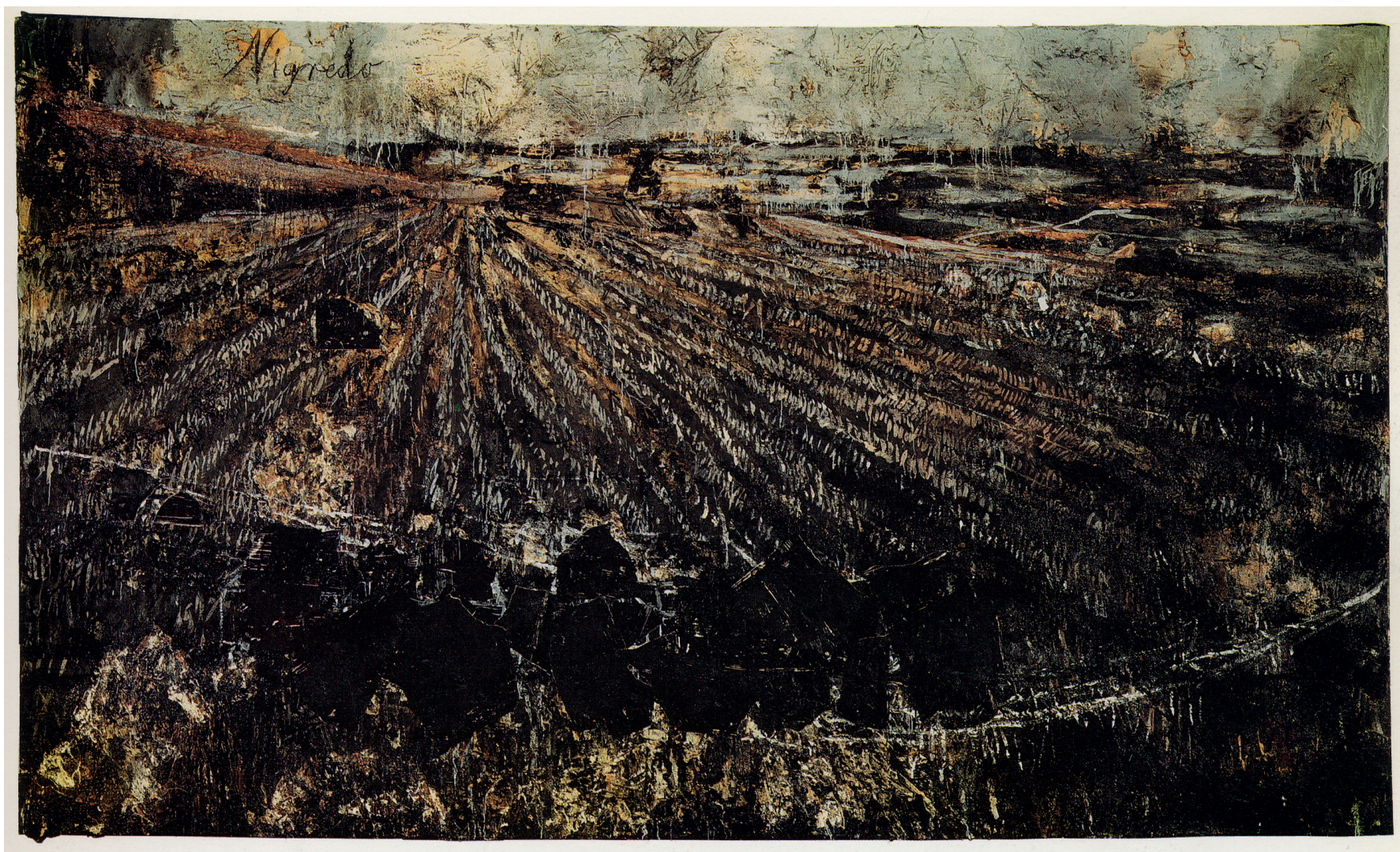

FIGURA 12. ANSELM KIEFER, NIGREDO, 1984

Técnica mixta sobre lienzo. Museo de Arte, Filadelfia. Foto: Manán.

En línea: http://sobrepintura.blogspot.com.es/2007/03/nigredo-de-ansel-kiefer.html (consulta: 22/03/2013).

una evocación constante de los modelos primigenios del laberinto y el observatorio, figuras complementarias que pueden representar la interioridad del mundo y su enigma, el tiempo, vinculado al ser por el cordón umbilical que simboliza el laberinto. El artista se propone tratar la luz que vemos en los sueños. Nacimiento y muerte, ambos son procesos en los que el ser humano atraviesa un túnel negro, un canal antes de emerger al espacio y a la luz (FIGURA I3). Este viaje, de fuera adentro, que invita a entrar en contacto con la propia interioridad, que provoca la reflexión, va acompañado por el miedo al temor, la aprensión; en definitiva, por el negro.

\section{CONCLUSIONES}

Cada color tiene su propia historia, entretejida en el tiempo como una construcción cultural compleja, caracterizada por innovaciones, progresos y cambios que han implicado mutaciones en sus significados simbólicos a través de nuevas prácticas y de sus usos cotidianos, dejando en ese transitar profundas huellas en los modos de pensamiento mediante su incorporación en el imaginario colectivo. 


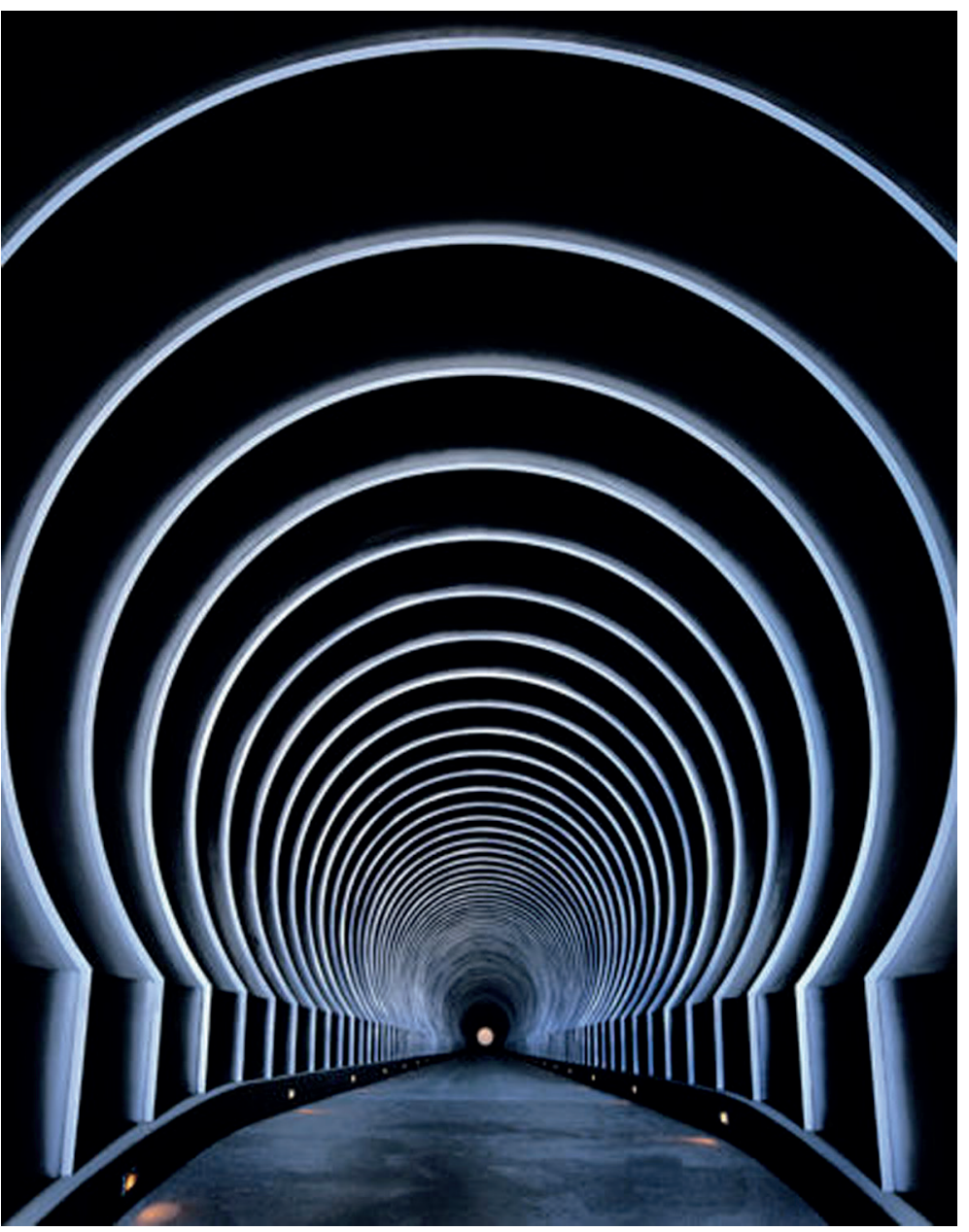

Este trabajo pretende poner en valor la enorme y rica carga significativa de la que es depositario el negro, un color que resulta fascinante por ser símbolo de la eterna opacidad, por servir como una pantalla o un velo que oculta e impide la visión, o por actuar como un gran contenedor que se abre al vacío, a la nada. En definitiva, un color terrenal donde se esconden todos los infiernos posibles.

Es, por tanto, una invitación a iniciar una reflexión sobre un color/no-color contradictorio, a la vez oscuridad y luz, dominado por las ideologías, liberado por los creadores, cuyo devenir se caracteriza por un balanceo constante entre tradición y modernidad. 


\section{BIBLIOGRAFÍA}

Adorno, Th. W. Teoría estética. Madrid, Taurus, I980.

- Philosophie de la nouvelle musique. París, Gallimard, I979.

Andersen, H.G.: L'Ombra. Turín, Einaudi, I970.

Areopagita, D.: Teología mística, I.I, en Martín Lunas, T.H. (ed.): Obras completas del Pseudo Dionisio A., Madrid, Biblioteca de Autores Cristianos, I995.

Ball, P.: Bright Earth. The invention of colour. Londres, Penguin, $200 \mathrm{I}$.

BAtAille, G.: La oscuridad no miente. Madrid, Taurus, 200I.

BÉrnardez, C.: Joseph Beuys. Guipúzcoa, Nerea, I999.

BRUSATIN, M.: Storia dei colori. Turín, Einaudi, I983.

BURKe, E.: Investigaciones sobre el origen de nuestras ideas de lo bello y lo sublime. Madrid, Alianza, 200I.

EliAde, M.: Le symbolisme des ténèbres dans les religions archaïques. Bruselas, Polarité du symbole. 2. ${ }^{\mathrm{a}}$ ed., I958.

Encrevé, P.: Soulages. Noir lumière, París, I996.

GaGe, J.: Colour and culture. Practice and meaning from Antiquity to Abstraction. Londres, I993.

Gutiérrez Pozo, A.: «Utopía en negro. El color negro en la estética negativa de Adorno y el Arte Radical Contemporáneo», en vv.AA.: Variaciones sobre el color, Universidad de Sevilla, 2007, pp.I87-208.

Hernández-Navarro, M.A.: «El cero de las formas. El Cuadrado Negro y la reducción de lo visible», en Imafronte, I9-20 (2007-08), pp. II9-I40.

Huxley, A.: Las cárceles de Piranesi. Madrid, Ediciones Casimiro, 20 II.

Joyce, J.: Ulysse. Barcelona, Lumen, I976, vol. I.

Kandinsky, W.: De lo espiritual en el arte. México, Premia Editora, I989.

KLEE, P.: Diarios I898-I9I8. Madrid, Alianza, I987.

Lemaire, G.-G.: Le Noir. París, Éditions Hazan, 2006.

Malevich, K.: The non objective world. Chicago, Paul Theobald and Co., I959.

MARCADE, B.: «Formalisme et négativité: notes sur le noir en marge d'une célèbre image de la Préface à la Phènoménologie de l'Esprit», en Artsudio, I6 (I990), p. 34.

Marulanda, V.: «La metáfora de lo negro: una aproximación a la estética de T.W. Adorno», en Ideas y Valores, 76-77 (I988), pp. 87-98. En línea http://www.revistas.unal.edu.co/index. php/idval/article/view/2I755 (consultada el Io/05/2012).

MÉnard, C.: «La bataille du noir et de la couleur», en Photo-Magazine, I5 (I9I2), p. I23.

Mollard-Desfour, A.: Le Dictionnaire de mots et expressions de couleur. Le Noir. París, CNRS, 2005.

Pastoureau, M.: «Morales de la couleur. Le chromoclasme de la Réforme», en Cahiers du Léopard d'Or, t. IV (I995), pp. 27-46.

- «La couleur en noir et blanc ( $\mathrm{xv}^{\mathrm{e}}-\mathrm{xvin}{ }^{\mathrm{e}}$ siècle)», en Le Livre et l'Historien. Études offertes en l'honneur du professeur Henri-Jean Martin. Ginebra, I997, pp. I97-213.

- Noir. Histoire d'une couleur. París, Éditions du Seuil, 2008.

REPLINGER, M.: «Sobre un color siniestro», en NEGRO. Catálogo exposición. Brasilia, Conjunto Cultural da Caixa, 2002. En línea: http://www.\$45839439I.mialojamiento.es/negroobras/negrocatalogo.htm (consultada el II/05/20I2). 
Stoichita, V.J.: Breve Historia de la Sombra. Madrid, Siruela, 2006.

VEGA, A.: Sacrificio y creación en la pintura de Rothko: la vía estética de la emoción religiosa. Madrid, Siruela, 2010.

vv.AA.: Phantasmagoria: Espectros de Ausencia. Catálogo exposición de arte contemporáneo, del 7 de marzo al 2I de mayo de 2007, Sala de Exposiciones temporales del Museo del Banco de la República, Bogotá.

vv.AA.: Bernardí Roig. Ejercicios de Reclusión. Catálogo exposición, Monasterio de Veruela, 2005.

vv.AA.: The Light-exercices series. Bernardí Roig. Catálogo exposición, Ministerio de Asuntos Exteriores y de Cooperación/Sociedad Estatal para la Acción Cultural Exterior, 2006. En línea: http://www.accioncultural.es/es/publicaciones/bernardi-roig-light-exercises-series (consultada el I4/05/2012).

vv.AA.: Monocromos. De Malevich al presente. Catálogo exposición. Madrid, Museo Nacional Centro de Arte Reina Sofía, Documenta Artes y Ciencias Visuales, 2004.

WARner, M.: Phantasmagoria. Spirit Visions, Metaphors, and Media into the Twenty-first Century. Nueva York, Oxford University Press, 2006.

YourCenAR, M.: A beneficio de inventario. Madrid, Alfaguara, 1987. 


\section{Dossier Cómplices Necesarios por Carlos Reyero Hermosilla - Dossier Necessary Accomplices by Carlos Reyero}

2) CARLOS REYERO

Introduction: Necessary Accomplices / Presentación: Cómplices necesarios

25 Encarna Montero Tortajada

The Oligarch and the Brushes: a Biographical Sketch of Andreu Garcia, priest / El oligarca y los pinceles: breve semblanza del presbítero Andreu Garcia

María Alegra García García

Some aspects about archbishop of Toledo don Juan Martínez Silíceo's iconography (c.1477-1557) / Algunos aspectos en torno a la iconografía del arzobispo de Toledo don Juan Martínez Silíceo (c.1477-1557)

\section{FELIPE PEREDA}

Performing Doubt: the Art of Believing in Early Modern Spain / El ejercicio de la duda: el arte de creer en la España alto Moderna

\section{Jesús-PEdRo LoREnTE LORENTE}

The mouseion ideal reinterpreted as art colony on the outskirts of Darmstadt and Hagen / El ideal del mouseion reinterpretado como colonia artística en las afueras de Darmstadt y Hagen

\section{9}

NÚRIA FERNÁNDEZ RIUS \& NURIA PEIST

The photographic and the mediation system. Artistic, technical and commercial values in the beginning of photography / Lo fotográfico y el sistema mediador. Valores artísticos, técnicos y comerciales en los inicios de la fotografía

\section{Elena Marcén Guillén}

Real museum, imaginary museum. Considerations around the concept of museum as metamorphosis scenery / Museo real, museo imaginario. Reflexiones en torno al concepto de museo como escenario de metamorfosis

147 VICENÇ FURIÓ

Fame and prestige: necessary and decisive accomplices in the case of Hilma af Klint / Fama y prestigio: cómplices necesarios y decisivos en el caso de Hilma af Klint

\section{Miscelánea $\cdot$ Miscellany}

De la aljama a la primitiva construcción gótica. Reflexiones a propósito de la Catedral de Jaén en época bajomedieval / From the Great Mosque to the former Gothic construction. Some observations on Jaén's Cathedral during the late middle ages
199

TERESA IZQUIERDO ARANDA

Carpintero y maestro constructor en la arquitectura gótica valenciana / Carpenters and building mason in the Gothic architecture in Valencia $\left(14^{\text {th }}-15^{\text {th }}\right.$ centuries)

223

ANTONIO JosÉ DíAZ FERNÁNDEZ

El arquitecto madrileño Pedro de la Torre en Toledo y un retablo inédito localizado / The Architect of Madrid Pedro de la Torre in Toledo and a located unpublished altarpiece

24.7 Fernando R. Bartolomé García \& Laura Calvo García

Transformaciones en el retablo mayor de San Miguel Arcángel de Lazkao (Gipuzkoa). Del Barroco al Neoclasicismo / Changes in the main altarpiece of Saint Michael the Archangel in Lazkao (Gipuzkoa). From Baroque to Neoclassicism

\section{Francisco JaVIER LÁZARO SEBAStiÁN}

La renovación de la fotografía española a partir de la pauta estética del realismo. Un precedente formal y significativo en el reportaje de Eugene Smith sobre Deleitosa (Cáceres) / The renovation of the Spanish photography from the aesthetic guideline of the realism. A formal and significant precedent in Eugene's Smith photographic article on Deleitosa (Cáceres)

277 Javier Cuevas del Barrio

El posicionamiento de Sigmund Freud ante el Surrealismo a través de la correspondencia con André Breton / The position of Sigmund Freud regarding Surrealism through correspondence with André Breton

295 Alicia SÁnCHEZ ORTIZ

El vacío iluminado del negro / The illuminated void of black

317 Óscar MuÑoz Sánchez

Santiago Serrano (1970-1980): Hacia una pintura no aprehensible / Santiago Serrano (1970-1980). Towards a non-apprehensible painting

347 Antonio Jesús Sánchez FERnÁndeZ

Restauración y metamorfosis de los valores del patrimonio cultural / Restoration and Metamorphosis of the Values of Cultural Heritage

\section{Reseñas · Book Review}

375

Aricò, Nicola. Architettura del Tardo Rinascimento in Sicilia. Giovannangelo Montorsoli a Messina (1547-57). Firenze, Leo S. Olschi Editore, 2013. (AlICIA CÁmARA MuÑoz)

Combalía, Victoria. Dora Maar. Barcelona, Circe, 2013. (AMPARO SERRANO DE HARO)

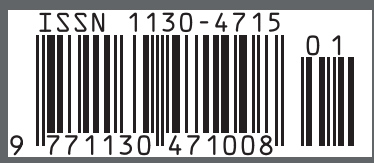

